Florida International University FIU Digital Commons

$8-1979$

\title{
A study of the top executive conference centers in the United States and an examination of the corresponding corporate meetings market
}

Howard Adler

Florida International University

DOI: $10.25148 /$ etd.FI13101531

Follow this and additional works at: https://digitalcommons.fiu.edu/etd

\section{Recommended Citation}

Adler, Howard, "A study of the top executive conference centers in the United States and an examination of the corresponding corporate meetings market" (1979). FIU Electronic Theses and Dissertations. 1159.

https://digitalcommons.fiu.edu/etd/1159 
A STUDY OF THE TOP EXECUTIVE CONFERENCE CENTERS

IN THE UNITED STATES AND AN EXAMINATION OF THE CORRESPONDING CORPORATI MEZTINGS MARKET

AN INDUSTRY PROUECT

Fresented to the Faculty of the Fotel School

of Florida International University for the degree

$0:$

Master of soience in

rotel and Food Service Management

by

Joward Adzer

August 1979 


\section{BIOGRAPHICAL SKITCH}

Eoward Adler grew up in the New York metropolitan area. After attending Miami Dade Community College and the university of Mevada, Las Vegas, he entered Florida International University in its initial semester and graduated with a Jachelor of science degree in Hotel, Food and Travel Management ln wus 1974 . During his undergraduate years he worked in management sapacities in several large Miami Beach notels.

After graduation he relocated in dalifornia so vegin a taaching career. Fe was an instructor of hotel and restaurant management at Los Angeles Valley College and Sadileback College, both in Southern California. Fe returned to the Kami area with his family in 1970 to complete his gracuate studies at Florica International University. Fe received his Waster of Science degree in Jotel and Restaurant Wanagement in August 1979. He is now an associate professor of hotel and restaurant Vanagement at the University of jouthern Mississippi. 
This paper is dedicated to $\mathrm{my}$ son, chaz who at tha time of the writing of this paper was two and one-half years old. Eis unspoiled smile gave me the incentive to complete this paper and continue on to the next step of my career. 
ACKIOWLEDGNENTS

I would like to express my thanks to Gerald Lattin, Dean of the school of Fospitality Nanagement. Fe has always offered his help when it was most needed throughout my Gracuate and undergracuate studies. Secondly, my thanks to those faculty members who offered their advice on this paper. A special thanks to Professor Donald Greenaway whose positive reinforcement made it easien to complete this paper. Finally, there is no way to thank my wife, joan for all the countless hours she spent editing and typing this paper. 


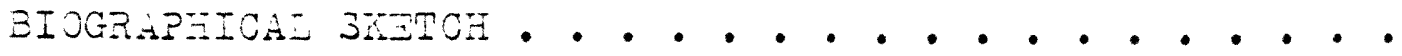

DIDICATION

ACKNONLEGMENTS

INTRODUCTION

CHAPTER I. BACKGROUMD ON THE CORPORATE MEZMIMGS

$$
\text { MARYET • • • • • • • • • • • • • • • }
$$

iii iv

A. Numbers and types of meetings

3. Tupes of companies holding meetings in relation to nature and size . . . . . . . .

c. Geographic location of corporate clientele and of conference center . . . . . . . . . . .

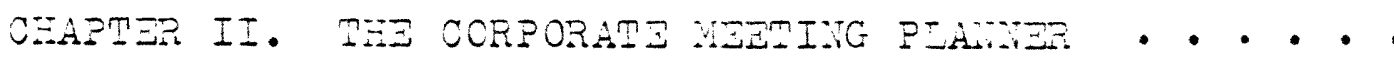

A. Definition . . . . . . . . . . . . . 10

3. Expenditures ior corporate meetinss $\cdot$ - * * * 10

c. Meeting planner's level of responsibility . .

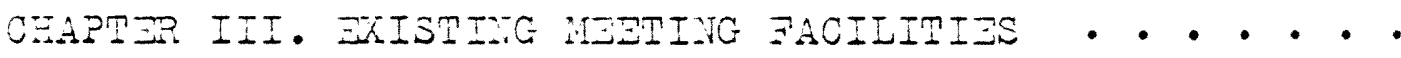

A. Introauction . . . . . . . . . . . . . 15

3. Tupical meeting facilities . . . . . . . . .

c. Selection of existing meeting facilities . .

CEASTER IV, CROWTE ATD DETELOPVENT OF TEE CONEZREICE CENTER CONCEPT

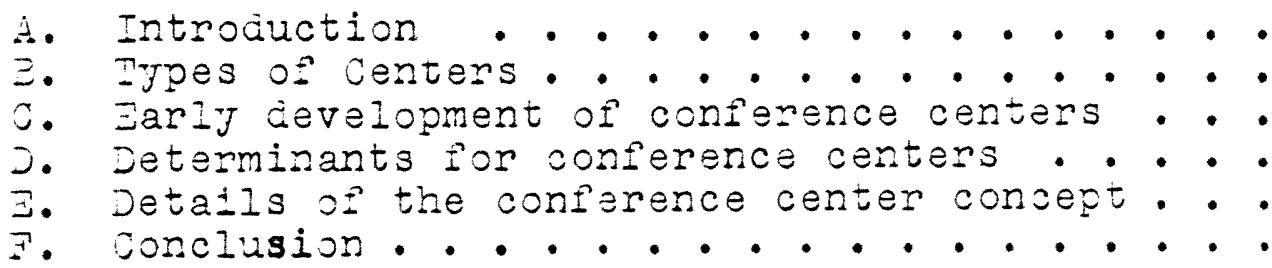


CHAPTER $Y$. CONPERENCE CENTIR SURVEY

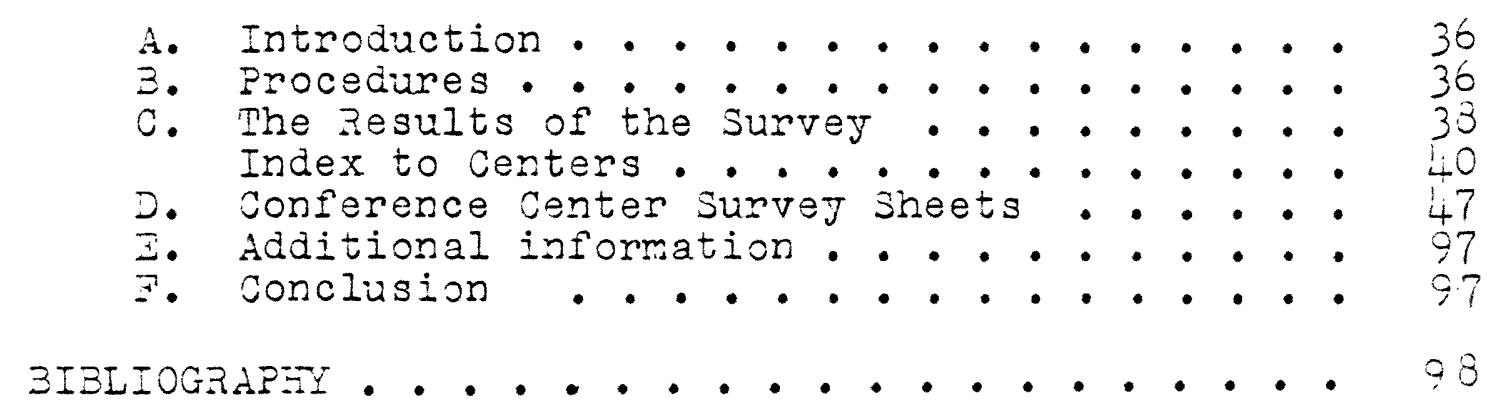




\section{INTRODUCTICN}

\section{THE IMPORTANCE OF THE STUDY}

The United States today has become "meeting-conscious." The complexity of conducting business has led to the need for sophisticated coordination of decision-making processes on all levels of the organization. Company meetings have played an increasingly important role in the success and future of many companies. Strategies and decisions are developed at meetings that can determine future policies of crucial importance. Executive training can mean the difference in whether the company will even survive.

Large and growing companies have increased their offpremise meeting budgets annually in spite of the state of the economy. Fowever, the rising costs of travel and lodging have made management monitor these budgets more closely than ever. Thus, the need to use every dollar efficiently has compelled companies to examine newer methods of running meetings and alternatives to the usage of typical off-premise meeting facizitias. The importance of off-premise meetings in the united States economy has greatly increased due to the billions of dollars spent annually. These factors make it vital to explore the effeciveness of time and monetary expenditures. 
Up until the mid-1960's, company meetings were held in facilities of various design and purpose, none of which were specifically designed for the small to medium corporate meeting. Upon gathering information concerning the meetings market and the corporate meeting planner, certain individuals endeavored to change the situation. This study is designed to investigate this new concept, which will hereafter be referred to as "conference center." For the purpose of this study, the following two definitions will be used.

1. Conference center - that meeting facility primarily marketing its facilities for the small to medium-sized corporate meeting. The center is operated by specialists aware of market needs in as much detail as are those people working for the company involved. On-premise sleeping rooms are not mandatory provided such facilities are within easy access.

2. Heeting planner - that person within an organization who has primary responsibility for arranging off-premise meetings and all other related items necessary for meeting effectiveness. This person may spend anywhere from 10 to 100\% of his time in this capacity.

The conference center has effectively satisfied the need fon specialized corporate meeting facilities. This study will show the depth of the corporate meetings market and trace the growth and development of this relatively new conference center 
concept. Information will also be compiled on the top centers in the country. It is hoped that by presenting this research meeting planners will become more aware of the nature and location of these centers, especially for use by the small to medium-sized company. Such exposure of the centers will hopefully increase existing demand and enable the construction of new, innovative centers. 
BACKGROUND ON THE CORFORATE MEETINGS MARKET

A. Numbers and Types of Meetings

In order to evaluate the meetings market, it is first necessary to examine the total number of meetings and the expenditures made on them. The most recent figures for the total number of off-premise meetings in the 1976-77 year are indicated as : 1

\begin{tabular}{lrl}
$\begin{array}{l}\text { Corporate Vietings } \\
\text { Association Veetings } \\
\text { Major Conventions }\end{array}$ & $\begin{array}{r}602,000(81 \%) \\
126,000 \\
11,500(17 \%)\end{array}$ \\
\hline Total Meetings & $\frac{739,500}{2 \%}$
\end{tabular}

For the purposes of this study, we are primarily interested in the 602,000 corporate meetings. These corporate meetings are the primary users of the types of conference facilities this study is concerned with. These meetings can be further broken down into the following categories by total number of meetings and attendees. ${ }^{2}$

Nanagement meetings

Training seminars

Cegional sales meetings

New product introductions

Professional/technical meetings

Tational sales meetings

$\begin{array}{rr}155,000 & 26 \% \\ 149,000 & 25 \\ 102,000 & 17 \\ 60,000 & 10 \\ 55,000 & 9 \\ 30,000 & 5\end{array}$

1. "The Heetings Narket, 1976-77", Meetings and Conventions Uagazine Annual Report, $1976-77$, p. 2 .

2. Ibid., p. 7 . 
Incentive trips

Stockholder meetings

other miscellaneous

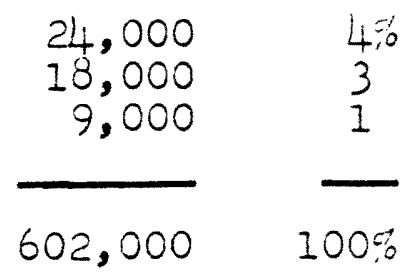

Total

$602,000 \quad 100 \%$

The subsequent chart lists the same meetings as the above, but by total number of attendees and per-cent of attendance. 3

Ivoes of meetings

Attendance

in prior jear

Regional sales meetings Management meetings

Professional/technical

New product introductions 6

National sales meetings

Training seminars

stockholders meetings

Incentive trips

Other
$7,960,000$

6,510,000

$6,160,000$

$6,000,000$

$5,370,000$

$5,220,000$

$5,000,000$

$3,790,000$

270,000

$$
\overline{46,280,000}
$$

Percentage of total attendance

TOTAL

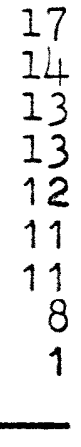

100

By examining these figures it is possible for a conference facility to market itself more efficiently. This involves a thorough examination by the facility of its resources and capabilities. At this point the conference center could then make a determination as to which types of meetings their property should be marketed towards. This method would insure a proper matching of the facility's size and capabilities and the appropriate group's needs.

3. "The Veetings Narket, 1976-77", op. cit., p. 9. 


\section{B. Types of Companies Holding Meetings in Relation to Nature and Size}

Once a conference center has determined those types of meetings it is most suited to handle, it must then study the source of those meetings. A conference center must then evaluate the nature of those organizations holding the types of meetings the facility is trying to attract. The following chart provides the sources of meetings in relation to the nature of the organization holding them. 4

\section{Source}

Business organizations Nonprofit trade and propessional associations Ecucational institutiona Government Professional seminar organizations keligious, other $\frac{\text { Percent of }}{\text { Total }}$

$$
\begin{gathered}
57.8 \% \\
16.5 \\
9.3 \\
8.0 \\
4.9 \\
3.5
\end{gathered}
$$

100.0

The potential importance of such information stems from the fact that certain organizations by nature would frequent specific types of facilities due to the organization's unique needs; e.z.: nan-profit versus big, corporate meetings. In the same vein, a further breakdown of company productivity is vital to ascertain the magnitude of a business the

4. David Arnold, The Ixecutive Conference Center: A Statistical and Financial Profile (Philadelphia: Laventrol i Eor'vati, 1977), p. 10 . 
conference center will be dealing with in respect to the company's dollar value and the number of employees. The following chart lists the dollar volume of those companies that held the 602,000 meetings mentioned earlier. 5

Under $\$ 1,000,000$

$\$ 1,000,000-\$ 4,999,999$

$\$ 5,000,000-\$ 9,999,999$

$\$ 10,000,000-\$ 49,999,999$

$350,000,000-399,999,999$

$\$ 100,000,000$ and over
$19 \%$

11

36

12

25

Total corporate subscribers $100 \%$

For the types of companies discussed above, only $14 \%$ had 5000 or more employees. The largest block of companies or $19 \%$ had between 1000 and 5000 employees. 16\% of the companies, which could be classified as medium-sized companies, had between 500 to 1000 employees. $18 \%$ of the companies had between 250 and 500 employees, and $16 \%$ had between 200 to 250 employees. The last $17 \%$ is comprised of those companies with fewer than 100 employees. 6 This $17 \%$ can be a significant segment of the market to increase.

C. Geographic Location of Corporate Clientele and of Conference Centers

The conference center market is in a constant state of flux. Therefore, it is necessary to observe the geographic

5. "The Neetings varket, 1976-77", op. Cit., p. 26. 6. Ibid. 
location of attending conferees. The following chart notes the geographic location of conference centers and where meeting attendees originate.?

$\frac{\text { Location of }}{\text { center }}$

Northeast Southeast North Central South Central iest
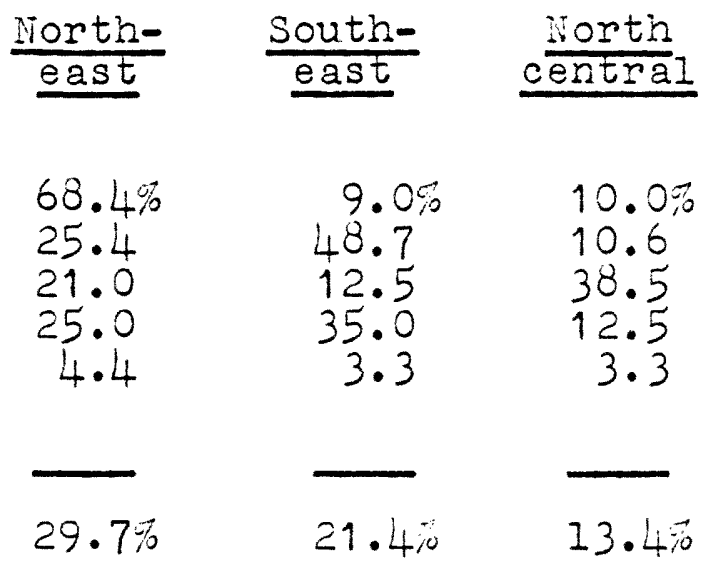

$29.7 \%$

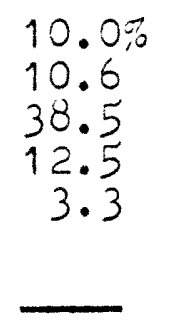

$13.4 \%$
$68.4 \%$ 25.4 21.0 25.0 4.4

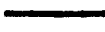

TOTAL
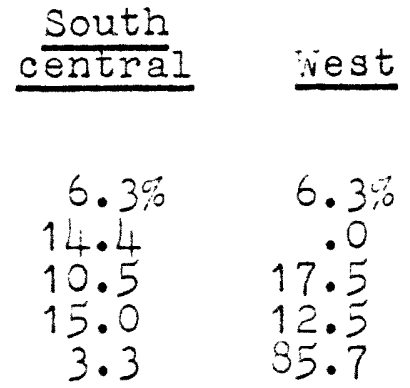

$6.3 \%$

.0

$17 \cdot 5$

12.5

85.7

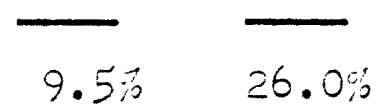

Nearly one-third of the meetings were regional, slightly over 30 percent were local, 28 percent were national and only 8 percent included conferees from outside the united states. 8

In order to market the center effectively, it is vital to know what type of meetings are being held in terms of local, regional, national or international category. The following chart will show which types of geographic meetings are held in various centers through the jnited states. ${ }^{9}$ (See page 10).

7. Arnold, Op. Cit., p. 11

8. Ibid.

9. Ibid., 0.12 
Eocation of Center

Loc a I

Regional

Tational

International

(markets)

Northeast

Southeast

North central

South central

West

$\begin{array}{lll}16.7 \% & 53.5 \% & 20.0 \% \\ 52.7 & 30.0 & 14.7 \\ 11.5 & 30.0 & 55.0 \\ 7.5 & 10.0 & 62.5 \\ 51.7 & 31.7 & 10.0\end{array}$

$10.0 \%$

3.3

3.5

20.0

6.6

TOTAL

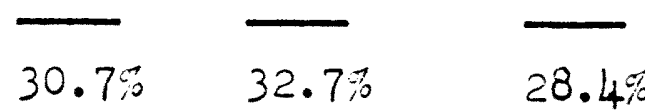

$8.2 \%$

The above figures show that the mid-continent centers are getting more national meetings because of their location. It also shows that South Central centers get more international business because of their location.

Transportation to conference-type facilities is primarily hy air. The subsequent chart illustrates the frequency of transportation used. 10

Scheduled, commercial airlines $74 \%$

Personal Car

Rental Car

Charter Airline

Sus

Company Car

Company Airplane

Train

Iimousine

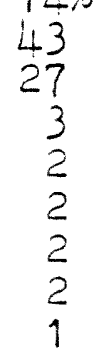

10. "The Neetings Market, 1976-66", OD. Cit., p. 17. 
THE CORPORATE MEETING PLANNER

A. Definition

For purposes of this study, the meeting planner, as previously defined, is the person within an organization who has primary responsibility for arranging off-premise meetings and all other related items necessary for meeting effectiveness. A thorough examination of the corporate meetings market must take into consideration the corporate meeting planner. In many cases a meeting facility would be unable to identify any other person with the authority to make meeting arrangements. Therefore, it is important to be able to pinpoint those individuals who are identified as corporate meeting planners.

\section{Expenditures for Corporate Meetings}

The 602,000 meetings, mentioned earlier, accounted for over 3.3 billion dollars in expenditures. 1.9 bizlion or 51 i was spent on hotel, food and related expenses. 1.1 bizlion or 29\% was spent on transportation, primarily air and 770 miziion or 20\% on miscellaneous exponses such as spenkers, equipment, etc. 11 The jollowing is a breakdown of expenditures made by 11. "The veetings varket, 1976-77", 0o. dit., ?. 6. 
corporate meeting planners. ${ }^{12}$

Less than $\$ 1,000$

31,000 - \$4,999

$\$ 5,000-\$ 9,999$

$\$ 10,000-\$ 19,999$

$\$ 20,000-\$ 29,999$

$\$ 30,000$ - $\$ 49,999$

$\$ 50,000$ - \$99,999

$\$ 100,000$ - $\$ 199,999$

$\$ 200,000$ or more

12

11

18

10

11

14

10

11

100

The above figures illustrate the power the meeting planner has in spending the company's meeting budget. Therefore, the conference center must understand the meeting planner's role in the organization and how far his decision-making responsibility goes.

C. The Neeting Planner's Level of Responsibility

Although corporate meeting planners spend large sums of money, that is not their only area of job responsibility. The following chart shows that two-thiras of corporate meeting planners spend less than 20\% of their time in actual meetine planning, implementation and final decision making. Percentages on the chart indicate the amount of his on-the-job time involved in off-premise meetings. 13 (see chart, page 12 ).

13. "The Veetings Narket, 1976-77", 20. Cit., p. 14 . 
Percentage of time

$1 \%=9 \%$
$10=19$
$20=29$
$30=39$
$40=49$
$50=59$
$60=69$
$70=79$
$80=89$
$90=99$
100

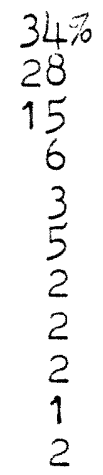

If a conference center is aware of the above information, then the center must also be aware that most of these meeting planners hold another job title accounting for the great percentage of their time. By recognizing this fact the conference center is better able to direct its selling effort towards that meeting planner because they are familiar with his corporate background. Due to the limited time the meeting planner spends in his role, the expertise of the conference center staff in dealing with him plays an increasingly important role.

35 per cent of all corporate meeting planners hola job titles in corporate administration while 31 per cent are involved in sales and marketing for the company. 16 per cent hold positions in advertising, public relations or sales promotion. Although the personnel and training departments are heavily involved in off-premise meetings, only 11 per cent of meeting planners come rrom various other departments within the organization. 14

14. "The lieetings Narket, 1976-77", op. Cit., p. 25. 
The conference center must be aware of the important areas in which the meeting planners have decision-making responsibilities. 87 per cent have decision-making responsibilities in the selection of the actual facility while only 83 per cent have such responsibility in the selection of the location of the meeting (i.e. region, city, etc.). 81 per cent have decision-making responsibility in the matter of whether the meeting should be off-center or not. In the area of meeting expenditures and budgets, 82 per cent have decision-making responsibility. 86 per cent and 34 per cent respectively have responsibility in establishing the meeting's objectives and agendas. EinnIly, 80 per cent of meeting planners have responsibility in the area of entertainment and othor social events of the meetings. 15

It is also interesting to note the above areas of responsibility in relation to the amount of time meeting plarners spend on them. The following is a list of functions in order of greatest time consumption spent by the meeting planner. 16

Establishing meeting objectives Planning of meeting agenda Selection of meeting hotel on other facility Establishing meeting expenditures/budget Selection of location of metting (city, area, country, etc.)

15. "The Yeetings Narket, 1976-77", Do. Cit., p. 21. 10. Ibid., p. 20 . 
Decision to hold off-premises meetings

Planning entertainment and social functions, sports tournaments

Trade show planning and exhibit planning

Rental or purchase of audio-visual equipment

Planning for air travel arrangements

Planning far ground transportation

Each of the above areas is very significant to the conference center in its unique way. The decision to pick a certain area of the country and a specific facility might orten come before the objective of the meeting and its agenda is planned, but not always. Thus, it is vital for the conference center to have this understaniing so that the may be involved in the stages of decision-making. This is crucial due to the lead time involved in planning most meetings. The average lead times for meeting planners and conference centers for the types of meetings discussed in this research are as follows: 17

Type of Neeting

Incentive trips

National sales meetings

Trade shows

Stockholder meetings

Frofessional technical meetings

Vew product introductions

Training seminars

Regional sales meetings

vanagement meetings
Lead Time

6.2 months

6.0 months

5.9 montins

4.3 months

4.1 months

3.6 months

3.5 months

3.5 months

3.0 montis

17. "The Neetings Narket, 1976-77", 00. Cit., p. 22. 


\section{CHAPTER III \\ EKISTING NEETING FACIZITIES}

A. Introduction

Heeting planners are frequently forced to accept space at facilities so inadequate that they must compromise and lower their expectations. Conditions contrary to meeting effectiveness are routinely accepted as normal circumatances. Thus, meeting planners often receive complaints from top management for some deficiency originating from the facility. Upon holding meetings at conference centers, these same meeting pianners and executives found their problems to be almost noneexistent. Correspondingly, their whole attitude concerning the use of outside meeting facilities was changed. Reasons behind this difference will be further examined.

\section{B. Typical Neeting Facilities}

Companies and meeting planners interested in holding meetings have a number of options regarding the type of facilities available for holding meetings and trainine seminars. Following are the most commonly used facilities with advantages and disadvantages.

1. Downtown on Commercial Fotels 
Advantages: Located in major metropolitan area with its usual availability of restaurants, theaters, shopping, sightseeing, etc. Usually located within reasonable proximity to major airports with good ground transportation. Might also be located near corporate or brance offices of company holding the meeting.

Disadvantages: تustle-bustle atmosphere of downtown area not conducive to many types of meetings. May detract from concentration of attenciees. This type of large convention hotel often has many large convention groups as well as up to a dozen meetings going on that are not related in purpose to your own. This detracts from the efficiency of the people who are handing you. This type of hotel often does not have the necessary recreational amenities, although it may have a health spa and a pool.

\section{Airport Fotel}

Advantages: Located in or within a few miles of the airport. Transportation to the hotel is usually very easy. This type of hotel usually gets short, intensive-type meetings.

Disadvantages: Hotel may not be entirely sound-proof. This type of hotel may not have many recreational amenities. The hotel itself may not be close to any kind of outside activity such as the downtown area. The facility may not have adequate parking. Also, the airport atmosphere of constant arrive and departing airplanes is not conducive to a productive, business atmosphere. 


\section{Resort Eotel}

Advantages: May have resort-type, relaxed atmosphere in relation to climate. It may be a specific, purpose-oriented resort with gambling, tennis, golf, etc. There are usually many other types of recreational amenities such as boating, horseback riding, etc. Nay also be located in an excellent sightseeing area. Way be climate-oriented, e.g.: beach resort, mountains, skiing.

Disadvantages: Very little actual business may be accomolished due to distractions of resort atmosphere and actvities. The mixture of tourists, conventioneers, etc. detracts from the meeting. 18

\section{Other various types of facilities}

Other types of facilities that may also be used for meetings are suburban or motor inns, country clubs, condominium resorts, cruise ships, university-operated centers, sporting lodges, etc. All of the previously mentioned facilities often have the confusion of numerous people congregated at the same place for varied purposes. Toise and congestion problems are also present. Nany of the distractions are internal, e.E.: poorlydesigned guest and meeting rooms, insufficient lighting, uncomfortable furniture, lack of support of audio-visual equipment and poorly-trained personnel handing meeting arrangements.

18. Lonald $\Xi$. Lundberg, The Zotel and Restaurant Business (Boston: Cahners 3ooks International, Inc., 1976), Chapter 2. 
The major problem with many of those facilities is that they are catering to many different market segments simultaneously. Their main concern is filling beds, restaurant chairs and bar stools.

Realizing the disadvantages involved with hotel-type locations for specific type format meetings, many organizations built plush conference facilities into their corporate or regional headquarters. These have also proved less than desirable because of factors such as frequent, outside telephone calis and other office crises. These types of interruptions work against the benefits of a controlled environment conducive to learning. Another undesirable factor is when the conferee abruptly returns to external affairs such as going to lunch or going home for the evening. Any learning momentum can be easily lost and must be re-established, thus wasting valuable time.

C. Selection of Existing Neeting Facilities

Nost companies generally use a variety of different facilities for their meetings throughout the year. The following is a breakdown of the most commonly used meeting facilities. ${ }^{19}$

Tye of Facility

Midtown hotel or motor inn Suburban notel or motor inn Resort hotel
Percentage of comonises usine facility

\footnotetext{
19. "The Heetings Narket, 1976-77", op. Cit., p. 13.
} 


\section{Type of Facility (CON'T.)}

Airport hotel or motor inn

Privately-owned conference center

University-owned conference center Condominium resort

Cruise ship

Sporting lodge/private club

(volunteered)

Auditorium/theater (volunteered)
Percentage of compantes

using facility

38

14

7

3

1

It is vital to note, then, why companies use the above facilities in relation to their location. In choosing a destination a company must first $100 \mathrm{k}$ at whether there are hotels or other facilities suitable for meetings in the area. This item is foremost since, if the area has no suitable facilities, the company must look elsewhere for a meeting location. Since modern meeting facilities can be found in most geograpicic areas, it is just a question of matching the most suitable location to the specific type of meeting.

Nost companies consider ease of transportation for meeting attendees to be the second most important factor in choosing a location. The attendees actual travelling distance is also significant, as is the ultimate cost of the transportation. There are very few meeting sites in the country that are not within thirty minutes to one hour from an ainport located in a medium-sized city offering reasonable connections. Yany are within the same distance from major airports located in the barge metropolitan areas. Finese time factors are a 
major consideration in planning the location. The site should not be on the East coast if 75 percent of the meeting attendees are coming from the Nountain on western states. Length and importance of the meeting are two other variables to be considered. If a management meeting is only going to last two three days, then there is no point having attendees spencing up to one hour reaching their destination from the airport alone unless tine meeting is so secretive or of such importance that it requires it.

Significant secondary factors in choosing the meeting site will obviously vary according to the type of meeting, e.8.: incentive meeting, stockholder meeting, etc. Climate plays only a somewhat important role as a location determinant. Availability of recreational facilities such as golf, tennis, swimming, although important, usually plays a minor role to the person planning the agenda. (However, evidence is beginnine to indicate that this last factor is playing an increasingly important role in site selection). Other areas of lesser importance in the final determination of location are such things as the glamorous image of the locatiin, sightseeing and other extra-curricular activities. 20

Jnce destination factors are considered and location is selected, the specific facility must be chosen. The type of meeting being held would be the determinant as to whether the

20. "The Neetings Narket, 1975-77", Co. Oit., o. 12. 
meeting would be better suited for a resort location or an isolated facility.

when a meeting facility is being chosen, specific items must be considered that can either "make or break" the success of the meeting. The subsequent factors are listed in order of importance in percentage rank as to the consideration they are given by a company and the meeting planner. 21

Quality of food service

Number, size and caliber of meeting rooms irumber, size and caliber of sleeping rooms Efficiency of billing procedures

Frevious experience in dealing with facility and its staff

Efficiency of check-in/check-out procedures

Assignment of one staff person to handle

all aspects of meeting

Availability of meeting support services and

equipment, such as audio-visual equipment

Proximity to airport

Convenience to other modes of transportation

Provision of special meeting services, such as

pre-registration, special equipment, etc. 20

on-site recreational facilities, such as golf,

swimming pool and tennis courts

Availability of exhibit space

Number, size and caliber of suites

Froximity to shopping, restaurants, off-site entertainment

Newness of facility

77

47

42

40

39

22

20

17

17

13

9

21. "The Meetings Market, 1976-77", Op. Cit., p. 15. 
GRONTH AND DEVELOPYENT OE THE

CONFERENCE CENTER CONCEPT

\section{A. Introduction}

All of the previously mentioned meeting problems resulted in the development of the executive conference center concept. The primary purpose of conference centers is to satisfy and accommodate conference groups by offering selfcontained, full-service learning and living environments. Jue to specific requirements of this market, these centers provicie specially designed meeting, lodging, dining and recreational facilities with appropriate atmosphere, accommodations and services. This total meeting environment is integrally designed and controlled by professionals with a knowledge of meeting planning and hospitality management. 22

Hany of the facilities used by companies in the past provide for only the minimum of needs. It must be noted that many attendees are top, corporate executives earning the highest salaries with tastes and needs requiring great consideration. other conference attendees, although not as high on the corporate ladder, also require a high degree of consideration because of 22. Nalter A. Green., "The Conference center concept," "eetinss
and Conventions, July $1973, \mathrm{p}$. 14 . 
the large investment companies are making in them for the future.

A successful meeting is comprised of many elements. opinions vary regarding the importance of each area. An average breakdown could be as follows: the program consisting of a skillful agenda and accurate subject focus would contribute to approximately 35 per-cent of meeting success. Effective speakers, trainers and discussion leaders can account for up to 40 per-cent of meeting success. Administration regarding workbooks, handouts, instructions, badges, etc. accounts for about 5 per-cent. And lastly, total meeting environment in which the attendee learns, relaxes, studies, eats and sleeps is said to account for only about 20 per-cent of total meeting success. 23 This study is concerned with this $20 \%$ because in past years this area was given very little consideration for being as valuable as it is.

Types of facilities currently holding meetings have been discussed in a previous section. The actual "conference center" is the facility which most completely meets the needs of the corporate meetings market. The corporate meetings market usually holds meetings that $c$ an be broken down into three basic categories regardless of the types of meetings they are. The training meeting, which is usually oriented toward smaller zroups, is ained at developing sirills and applying knowledge.

23. Nilliam I. Kaiser, "Conference Centers," Weetines and Expositions, Septemier 1976, p. 18. 
This type of meeting can be a sales meeting, an orientationtype meeting for new executives, etc. and is usually run by a skilled trainer. The decision-making meeting is run by an executive with the purpose of developing or accepting a specific plan of action. The last type of meeting is the most general. It can be considered an informational meeting, and its size may range from twelve to several hundred participants. This type of meeting may be designed to stimulate new ideas or just disseminate policy statements or progress report. Folding any of these meetings in their traditional facility can result in unsatisfactory outcomes due to the fact that the facility handing them, as mentioned earlier, may also be in the specialty restaurant business, banquet business or convention business.

\section{B. Types of Centers}

When discussing conference centers we encounter a certain amount of variation because of ambiguous terminologJ used to define a conference center. A conference center, as defined enrlier, is that meeting facility primarily marketirg its racilities for the small to medium size corporate meeting. The center is operated by spacialists aware of market needs in as much detail as are those people working for the company involved. For purposes of this study it is necessary to further cepine those caterories of conference centers meeting the above qualifications. 
The first type of conference center consists of those facilities that call themselves "conference centers" but are designed and operated lixe any other hotel. The fact that they use the term "conference center" is questionable. This type of facility is basically trying to capitalize on the new popularity enjoyed by the conference centor without providing the expertise and investment needed to be a true conference center.

The next tjpe of conference center is usuaily more isolated and offers more features corporate meetings require such as specialized staff, more ambience in the setting, etc. It will usually have from 100 to 300 rooms instead of the 300 or more the first center discussed might have. This smaller size obviously leads to more concentration for meeting attendees with group size from fifteen to forty people.

The third type of conference center is true to definition. This type of center not only attempts to remove the individual to an isolated atmosphere but tries to consider azl enviroments within which the individual interacts furing the entire 24 hours of a meeting day. 24

\section{Early Development of conference centers}

The key idea in evaluating the conference center concept is the phrase "specifically designed." The evolution of the 
conference center began with the search for alternatives to the hotel's physical and psychological environment in which business conferences had to be held. In the early 1960 's large corporations, stimulated by the behavioral sciences and the growth of educational technologies, began to realize that the employee was their most important resource. The use of training, at one time strictly limited to sales people, was directed to all levels of management. Education, in the field of management development, human resource development and skills training emerged at this point. The corporations had concluded that training costs and development were less costly than turnover and that key people switching from organization to organization was wasting company resources. In addition, training could also result in more promotions from within the company, thus giving the employee strong incentive and growth with the business. Companies realized, more than ever, that competition for promotion amons employees was directly related to business success. In conjunction with the development of formalized training programs, more specializec types of facilites were needed.

In the early 1960's the Conference Services Compary, under the leadership of president ialter creen studied this new, possible alternative for a specialized facility and any other similar meeting establishment. It was found that a need existed for the development of more centers. Horels, they 
concluded, could not handle the small to medium-sized corporate meeting with all its variations and requirements for preferred treatment, privacy and efficiency. This research spurred on the reed to explore further varicus options. 25

one of the earliest alternatives started when companies began using their own hunting lodges, country clubs, etc. for small executive meetings. In the 1950's the American Manasement Association took their manazement development program to the campus of Colgate University. AIso, in the fifties, Averill Iarriman donated Arden Fouse, the family estate in Farriman, Iew York to Columbia University. Today, it is the site for many Columbia-sponsored meetings and courses. The idea of using conference facilities on university campuses was not new, but it was expanding. In 1967 Green collaborated with steve Farrison, bought a 55-acre estate in Glen Cove, New York and transformed it into an executive conference center using the basic ideas they had learned. The conference rooms evolved from the mansion's living rooms, library, music rooms, etc. They tried to maintain the rooms in their original elegance to provide a home-like aura for the comfort of executives attending meetings. Earrison Conference center utilizes a concept capitalizing on service and the environment; six successful centers are now in operation.

Farrison personnel realize that most meeting planners are not full-time professionals. Thus, they attempt to assume

25. Edward Vatkins, "Meet the Neeting Experts," Hospitaity, September, 1976, p. 51. 
as much responsibility as possible. Nany times the meeting planner is also a meeting participant. Thus, iarrison tries to relieve him of problem areas so he can concentrate on business. This helps the planner to appear highly efficient. The meeting planner can work with one person from 7 a.m. to midnight who can expedite all details of the meeting. Thus, instead of dealing with different department heads the meeting planner can deal with this one conference planner regarding coffee breaks, food and beverage, check-in and check-out, credit, etc. Personnel attempt to satisfy all needs of the business meeting. Farrison centers were also the first ones to market their centers in a single packase price which included all rooms, meals, audio-visual equipment and service gratuities. 27

Harrison has a unique marketing approach in that their ntional, regional or local sales forces sell their clients on the conference center concept first, and then suggest which property can serve their needs best. The marketing staff does not get involved in finalizing meeting arrangements. Father, the operating management at each center closes the sale and works out further details. This eliminates the problem of "pushy sales people", the problem many typical meeting facilities have. These people may be good at closing the deal, yet poor at following through on meeting details. Farrison properties are marketed strictly at the corporate conference market. To increase business on a weekend, personnel attempt to utiIize weekend, resort business. These two sale functions, how- 
ever, are kept separate. Originally, weekend business was simply used to fill in gaps. However, now the number of conferences held on weekends has increased 70 per-cent in the last two years. Yany weekday meeting attendees stay over to use the center on weekends for relaxation and use of recreational facilities. In general, Harrison Conference centers have four patterns of occupancy: Monday through Eniday, Yonday through vednesday, Nednesday through Friday and Friday through sunday.

Hany conference centers, including Jarrison, have begun leasinz space to companies on a permanent basis. The company receives the benefits of the center without having to make a large capital investment. This arrangement has allowed conference centers to smooth out gaps in occupancy by being able to count on certain companies year-round. 28

\section{Determinants for Conference Centers}

A irequent problem, encounterez by many meeting planners, in their choice of conference center facilities, comes in the actual choosing of a center. Planners have often chosen socalled "conference centers" that are merelJ designed and operated like a hotel. Planners have found that these hotels use areas for meetings which are also used for fashion shows, banquets, proms, balls, conventions, etc. Yeetinas are treated as

23. "Conference Centers, Fulfizling Eusiness's Eressing ieeds", Cornel1 zuarterly, February 1973, p. 33 . 
appendages of the basic business of the hotel.

In looking at the criteria that must be included in a description of a total environment conference center, the following should be considered: 29

1. It should be unquestionable that the facility is first and last a conference center on a full-time basis.

2. It should be located in a non-commercial, con-industrial and natural setting.

3. It should provide a large number and wide variety of specially designed meeting rooms.

4. Its services and accommodations should represent a wholly self-contained atmosphere for participants who will be alternating business and relaxation activities over prolonged periods. It should not be a training classroom building with hotel or motel accommodations attached or nearby.

5. The management and staff personnel should be demonstrably professional on all levels of service for a wide variety of meetings.

6. The distractions of automobile, aircraft and people traffic---the competition of noise and movement that meeting professionals rank as the io. 1 annoyance--should be conspicuously absent.

7. The phjsical appearance should provoke an immediate affirmative response among the participants, creating an emphatic recognition of the company's reason ior selecting the site and the importance oi the meeting.

8. There should be an immediately perceptible blenc of amoience, comport and utility in the accommodations and services.

29. Green, op. Cit., p. 20. 
E. Details of the Conference Center Concept

The intensity of a meeting will determine the type of facility needed. If a meeting is of short duration (e.s. a few hours) and light on learning, then a local motel could satisiy the requirement. If the meeting is short and people are flying in from various parts of the country, an airport hotel might work. A resort can suffice if the conference is some kind of reward or incentive-oriented affair. Eowever, when the group is under 100 and usually between 25 - 50 people and the subject requires concentration as well as possibly a 12 - 18 hour daj of direct and indirect contact, then a conferonce center is the type of facility needed.

The conference center concept takes into consideration areas previously ignored. Feople who develop and design these renters want to use light colors or hues to keep meeting participants alert, because they have found that dark colors induce drowsiness. They try to keep room temperature around $60^{\circ}$ with a $40 \%$ humidity to encourage comfort. Chairs must be desinned to be adjustable to suit individual body differences, thus affording a strainless posture and avoid Iatizue. The chairs should have arms and be reasonably padded. (Mypical facilities use stack chairs which often are only good for three hours of comfort.) Weeting rocms should be square since this encourages 
participants to draw together and have discussions. Long, narrow rooms discourage this. Considerations have also been given to ceiling heights for different types of meetings as well as specially designed tables for different rocm sizes. Fotels usually use air walls that provide flexibility for meeting space. However, these are often not totaliy soundproof. Conference centers, on the other hand, tend to be composed of smaller meeting rooms, since most meetings the handle rall into the 25 - 40 attendee range. Weeting rooms are clustered in one area of the center away from possible distractions. In that same area, there is lisually a lounge or game room for use by meeting participants.

The smaller meeting rooms in conference centers are often equipped with low-glare, fluorescent lighting and individual control panels that permit occupants to adjust the temperature and ventilation for each room. Neeting rooms also have such features as extra electrical outlets, permanent blackboards, electrically-operated projection screens and closets for securo storage of participants' materials.

The efficiency curve is another area to be examined in terms of planning and timing agencas. Efficiency peaks after breakfast and holds fairly steady until a little before noon. Aiter a lunchtime low, it reaches a second high which is not quite as high as the morning one. This steadily declines until about 4:30 or so. There is a iift after the evening meal which then declines until bedtime. Meetings at these centers can be 
worked around particular group eficiency since most centers have only 100 to 200 rooms, and all people at the center are there for the same purpose. Cenerally speaking, most meetings last between three to five days. During thi- time the total environment of the facility has been performing in a complimentary way to help the group accomplish its objectives. Conference center developers nave noted that one of the single biggest problems of meeting planners has been the support systems in the traditional centers. Conference centers currently have items such as closed circuit television attached to all guest rooms and meeting rooms, rear screen projection equipment and a total audio-visual concept. The use of video tape allows meeting participants to view their performances for instructional purposes.

In the past, conference center guest rooms have been twin rooms for the most part. However, the center attempts to provide single occupancy for those meetings consisting of top executives. Guest rooms are at least as nice as typical meeting facilities. Fowever, the conference center tries to keep the attendee involved in the learning experience and out of his guest room, although the rooms do have study facilities for tio. The effectiveness of the people setting up the meeting arrangements, contacting the planner and following through is considered the most important item needed for overall success. These people handle the group in areas of audio-visual needs, 
and cperations, all the food service arrangements, recreacional facilities, etc. They are professionals who are not specifically trained in dealing with top, corporate people and not conventioneers or tourists. Conference centers have payrolls of up to $40 \%$ of sales to insure that each group has a specific person assigned to handle it. Each center may employ up to six such people to insure meeting continuity. These conference coordinators are trained to provide for a total service-oriented type facility with room for whatever flexibility is reeded. 31 conference centers are often found in beautiful surroundings, such as rolling hills. Some authorities feel this is necessary for concentration since the site is away from traditional distractions; others believe this atmosphere can be unproductive. Another area of controversy concerns recreation. Early centers provided for only a minimum of recreation amenities so that meeting attendees would concentrate on the task at hand. Today, conference center planners realize that physical fitness and occasional diversions produce more effective meeting results.

$$
\text { F. Conclusion }
$$

All companies should be seeking to achieve a greater return on every meeting dollar spent. It is therefore vital that meetings and training sessions attain their planned goals. The corporate meeting is more important than ever because stakes in large companies are so high. It costs more money to develop

31. Watkins, Jp. Cit., p. 51 . 
a concept that sells and more money to train management people who have the talent and dedication for the procuction of profits. These are the factors that have contributed to the growtin of conference centers. These types of conference centers provide the remoteness and relaxed place which free participants from deadine pressures, phone calls and demands For decisions. Some of the best known conference centers are housed in unique settings which at one time were estates for such people as Frank Lloyd iright and Averill Earriman. 


\section{CHAFTER V}

\section{CONFERENCE CENTER SURVEI}

\section{A. Introduction}

Jata has been compiled on those meeting pacilities in this country fitting the description of the so-called "conference center concept." Vany facilities, as previously mentioned in this study, call themselves conference centers but are not such in actuality as they often cater to many market sezments at one time. However, we have included them in this study. There is also a large segment of facilities holding hundred of meetings each year. These facilities are commercial, resort and airporttype hotels and the meetings they hold are of varied types. It goes without saying that they do not have the proper facilities that other more meeting-oriented facilities have.

\section{Procedures}

Letters were sent out to those centers moetins the criteria of conference centers, as outlined in this paper. The purpose of the stuay was explained and a questionnaire enclosed requesting assistance in providing any pertinent insormation. Letters were usually adaressed to the jirector of jales since this person would usually have the necessary information on the facilities and marketing patterns. The intent of the study was 
to compile data necessary for comparison purposes. This data could then be compared to data listed in the earlier parts of this study. When necessary, telephone calls were made to secure the same information that was sent in the mail. Iris was essential due, in part, to the failure of some facilities to respond and the time element involved in completing this study.

Data was collected from approximately firty different facilities. Some of the following information gathered irom conference centers will not be found on the individual survey sheets. All conference centers had at least one restalinant of the fine dining variety. Nore orten, these Pacizities had at least two and often more restaurants. All facilities had cochtail lounges, many with entertainment oi various types. Guest rooms were usually ol superior quality, including such amenities as color television, individual climate control, wake-up alarm, small refrigerators, direct dial telephones, heat lamps, etc. All conference centers had approximately $5-10 \%$ of guest rooms made into suites. The suites were often used for smali metings and contained such things as vet bars, kitchenettes, etc. Another area needing further discussion is the delineation of facility prices. The majority of facilities had thein rocm rate at one price, an aditional price for meals and meetine facilities and aditional fees for certain trpes of auaiorisual equipment. The true conference center had che price which included the price of room per person, two on three meals deperding on the center, coliee breaks, use of meetine rooms, 
standard audio-visual equipment including: tape recorders, phonographs, microphones, projectors, projection screens, remote control cords, portable stares, lectures, easels, blackboards. Many centers included, at little or no charge, use of closed circuit television, typewriters, duplicating equipment and trucks or vans. In adaition, all service gratuities are included. Another unique item in these centers is the extra support efforts they offer to companies and thein meeting planners (e.E. locksmitns, audio-visual operators, sien aisplay builcers, security guards, electricians, etc.

\section{c. The Results of the Survey}

All results are subject to a high degree of approximation. The person answering the questions often did not have the exact answers at their immediate disposal. Consequently, conclusions presented will, in themselves, be approximations. A significant point to note in reviewing the results of this survey is the fact that less than fifty per-cent of responding centers actually fit the standards set for the true "conference center." The map and kej located on the subsequent pages illustrate the concentrations of conference centers included in this survey. The following is a list of conference centers according to their location.

Northeast Southeast
$26 \%$

$14 \%$ 


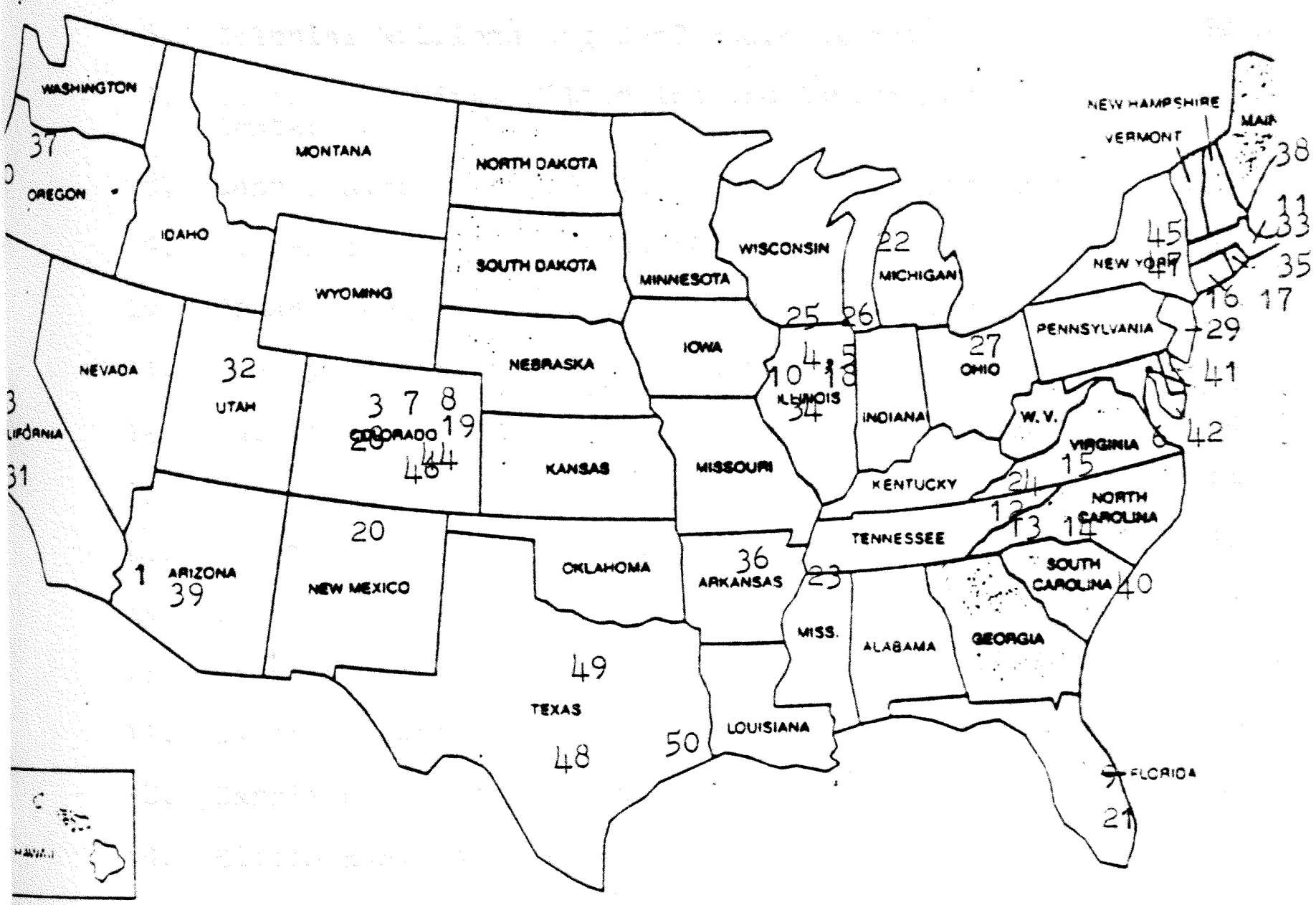


1. Arizona Siltmore Resort and Conference Center 47

2. Asilomar Conference Center

3. Aspen Meadows Conference Center

4. Carson Inn/Nordic Hills Resort/Conference Center

5. Chauteau Louise Resort and Conference Center

51

6. Solonial villiamsburg Conference Center

7. Colorado Springs Hilton Inn and Conference Center

0. Denver Airport jilton Inn conference Center

54

9. Dodgertown Conference center

10. Drake Cakbrook Hotel and Conference Center

11. Dunfey Fyannis Resort and Conference Center

12. Fairfield Glade Conference Center

13. Fairfield Mountains conference Center

14. Great Smokies Filton Resort and Conference Center 60

15. The Greenbrier

16. Jarrison Conference Center of Glen Cove 62

17. Harrison Conference Center of Eeritage Village 63

18. Farrison Conference Center of Lake 3luff 64

19. Filton Jarvest Fouse Resort and Conference Center 65

20. The Hilton Inn and Conference Center 66

21. Silton Inn and Conference center at Inverrary 6 ?

22. Filton Shanty creek Resort and Conference center b8

23. Foliday Inn Executive Conference Center 
INDEX TO CONFERENCE CENTERS (CON'T)

PAGE NUNBER

24. The Fomestead

25. Foward Johnson's O'Eare International Eotel and Conference Center

26. Indian Rock Resort and Conference center

72

27. Kings Island Inn Conference Center

28. Lion Square Lodge and Conference center

74

29. Viational Conference Jenter

75

30. Otter Jrest kesort and Conference center 76

31. Pajaro Junes Conference Center

32. Prospector Square Ski and Conference center

33. Provincetown Inn Executive conference denter i9

34. Pheasant Run

35. Ramada Inn-iyetro Neeting Center

81

36. Red Apple Inn and Executive Conference Jenter 82

37. Salishan Executive Conference Center 33

38. Samoset Resort Inn 84

39. Scottsale Conference Center 85

40. Sea Pines Conference Center 86

41. Shawnee Inn (Harrison Conference Center) 87

42. Sheraton International Conference Center 88

43. Silverado Resort and Conference Center 39

44. Snowmass Resort and Conference Center go

45. Sterling Forest Conference Center 31

46. Stonebriage Inn and Conference center 92

47. Tarrytow Jouse Conference Center 93

43. The Inn at Turtie creek 34

49. Twin Sixties Inn and Conference Center 95

50. The iroodlands Inn and country Club 96 
Northcentral $\quad 16: 0$

Southcentral $12 \%$

west $32 \%$

i. Results of distance from airport:

Most of the conference centers were between thirty and fortyfive minutes from a major airport and usually within five to ten miles from a local, municipal-type airport. "Limo" means arrangements were often made by the centers for transportation from local or major airport.

2. Results of trpe of facility:

Forty-five per-cent of the centers surveyed were located in resort-type locations. Twenty per-cent were located in commercial or airport locations. Thirty-five per-cent of centers were located in suburban or rural areas. The typical center surveyed was more on the resort side. The true conienence center was located far enough outside a metropolitan area to offer seclusion but close enough for good travel connections. Most centers were located in scenic surroundings.

\section{Results of recreational facilities}

$100 \%$ of the centers had swimming pools. At least fifty percent of them had more than one, and this was often an indoor, heated pool. 100\% of the facilities had tennis counts, usuzily with four on a premise. At least fifty per-cent of the courts were lighted, and the larger certers often had a few courts 
located indoors, depending upon the area of the country. Seventy-five per-cent of all centers had golf courses, many with a resident pro and driving range. The remaining twentyfive per-cent had a golf course located at a local country club not more than five or ten minutes away. Wany of the centers had such things as boating, fishing and other water sports, if located on a lake or by the ocean. Nany had sking nearby in seascn. Other activities in common were: skeet shooting, jogging trails, horseback riding, etc. The majority of all centers had health clubs including a gum, saunas, steam rooms, etc. Resort-tjpe facilities offered the most recreational amenities.

\section{Results of rate structure}

Less than thirty per-cent of the centers surveyed offered American plan meals or any package including meeting room facilities, audio-visual facilities, etc. Joss than twenty per-cent of the centers had an inclusive price per person. The inclusive price range was $\$ 75.00$ to $\$ 110.00$ for a sinele room to $\$ 100.00$ to 140 for a double room. Other types of facilities considered conference centers, rates ranged from approximately $\$ 30.00$ to $\$ 55.00$ depending on whether the facility had seasonal rates.

$$
\text { 5. Results of orizinal usage of the facility }
$$

Over 90: of all conference centers were not oniginallJ conference 
centers. Many were resorts that, due to location and Iacilities, have added additional conference space and cater more to that market. viany of the centers had never been hotel or resorts but were mansions or estates that were converted for use as a conference center.

6. Results of how meeting attendees arrived at locations and where they came from

Those centers located in the Northeast and irorthcentral areas of the country had the greatest percentage of meeting attendees from their geographic area. Nost arrived by oar or limousine. The remainder of meeting attendees were flown in by their large, corporate headquarters for the meetings. The remainder of the country used a high percentage of private aircraft coming in through smaller, local airports. Host centers had over seventy-five per-cent of meeting attendees coming from within a 500 miles radius of the facility.

7. Results of sources of business Only twenty per-cent of the centers had 95 to $100 \%$ of their business coming from the corporate meetings market yearly. The results ranged from seventy-five per-cent business, twentyfive per-cent transient and tourist for the commercial-type center to seventy-five per-cent tourist and twenty-five percent commercial for the more tourist-tjpe center. This depends on whether or not tine facility is seasonal. 
8. Results of types of meetings and attendance and duration

Most of the centers reported that informational-type meetings and training-type meetings were the most populan, pollowed by regional sales meetings and local saies meetings. Larger centers handled national meetings; the true conperence centers had more of the training and executive, management-type meetings. Incentive-type meetings were usually hald in resort oriented centers. Group size ranged from twenty to fifty and lasted three to four days depending upon the tjpe of meeting hela.

9. Results of percentaze of repeat occupancy

In those racilities closest to being true "conference centers", the percentage of repeat business was over eighty per-cent. other types of facilities averaged around fifty per-cent for meetings business. In resort-type facilities repeat business averaged at seventy per-cent for tourist busiress.

10. Results of pattern of weekly and jearly occuparcy In general, the fall and spring seemed to be the heaviest months for business meetings. In the true "conference center" a fairly constant occupancy appeared year-rcund. In the more, resort-oriented facility there was a lessening ô business meetings in the vacation months, both winter and summer. Jusiest occupancy periods were Sunday nights through Friday. Fowever, many centers were reporting increases in numbers of week-end meetings. 
11. Results of why companies chose the facility

Most companies reported choosing particular centers for their location and excellent staff and facilities. These companies felt they were being handled by very professional people and given special considerations. They also felt that the assignment of one person handing all their needs made certain that all details were followed up.

12. Results of competition

There were at least five centers that reported they had no airect competition. Many other centers reported their only competition was conference centers like themselves. The remainder reported that their competition was meeting facilities in general.

\section{Conference Center Survey Sheets}

The following fifty pages are composed of indiridual survey sheets for each of the conference centers responding to the survey. 
Name of Facility: Arizona Biltmore Resort and Conference Center Address: Missouri at 24th Street, Phoenix, Arizona

Contact Person: Patrick McFarland, Director of Sales

Distance from Airport: 15 minutes from Skyharbour International Airport in Phoenix.

Type of Facility: 318 rooms in main wing and with cottages on large desert-type facility with Aztec-style influence.

Sizes of Meeting Rooms: 12 meeting rooms in total. Grand 3allroom, $92 \times 81$; Aztec Room, 57 x 54; Paradise Room, $23 \times 33$; Arizona Rooma, $26 \times 20$.

Recreational Amenities: heated swimming pool, 17 tennis courts, 15 which are lighted; 36-hole golf course, healtin club, biking and jogzing trails.

Rate Structure: Iuropean plan (with American plan available), single/ double $\$ 30-105$.

was it originally a conference center? originally a 5-star resort which began to cater to higher level meeting.

Ideas used to make your facility unique from others: high qualityoriented meeting facility.

Percentage of business arriving by air, car, etc., and from what section of the country: $80 \%$ of all business arrives through airport, comes from Nest Coast, Texas and Midwest. Remainder comes in from surrounding area by car.

Sources of your business: approximately 50\% of businesses is vacation and 50\% meetings related. Fowever, is seasonal.

Types of meetings most commonly held at jour facility: naticnal sales meetings, regional sales meetings, new product meetings, and large association meetings.

Average attendance and duration or meetings: up to 1 week with over 50 people.

Percentage of repeat business: 50\% of meetings business is repeat. Fatterns of weekly and Jearlj occupancy: occupancy heavj during entire week.

Reasons companies have chosen jour facility over others and reasons they return: very high quality of all amenities and meelng jacilities 
Name of Facility: Asilomar Conference Jenter

Address: 800 Asilomar Boulevard, Pacific Grove, California

Contact Person: Jane Fisher, Director of Sales

Distance from Airport: 10 miles from Monterrey Airport

Type of Facility: 314 rooms located in villas on the ccean.

Sizes of Meeting Rooms: 25 total meeting rooms

Recreational Amenities: 18 hole golf course, outdoor pool, horseback riding, 6 tennis courts.

Rate Structure: not available

was it originally a conference center? originally a condominium development.

Ideas used to make jour facility unique from others: not available

Percentage of business arriving by air, car, etc., and from what section of the country: majority of guests drive in from san Francisco and Los Angeles areas. Remainder fly into local airport.

Sources of your business: $25 \%$ meetings business; $75 \%$ vacation, resort

Types of meetings most commonly held at jour facility: incentivetjpe meetings, national sales meetings.

Average attendance and duration of meetings: 75-100 persons, 5-7 dajs.

Percentage of repeat business: not available

Patterns of weekly and jearly occupancy: business meetings ronday through Saturday, vacation business Thursday through Sunday.

Reasons companies have chosen jour Pacilitj over others and reasons they return: ambience of surroundings.

where is jour major competition: other facilities in :onterrey area. 
Name of Facility: Aspen Neadows Conference Center

Address: 845 Neadows Road, Aspen, Colorado

Contact Person: Susan Mac Michael, Sales Nanager

Distance from Airport: 1 mile from Aspen airport

Type of Facility: low-rise lodge, comprising ga just rooms.

Sizes of Meeting Rooms: 11 meeting rooms

Recreational Amenities: health club, outdoor pool, nearby skiing, tennis courts, $301 \mathrm{f}$ at nearby country club.

Rate Structure: American plan, single s72; double 3117.

Was it originally a conference center? no, a resort facility

Ideas used to make your facility unique from others: not available

Percentage of business arriving by air, car, etc., and from what section of the country: 90, arrives through Aspen Aipport from Midwest and ivest Coast

Sources of jour business: $65 \%$ resort; $35 \%$ business

Types of meetings most commonly held at jour facility: small training meetings and management meetings

Average attendance and duration of metings: 20-30 people, 4 days

Percentage of repeat business: not available

Patterns of weekly and Jearly occupancy: spring and fall busiast meeting months; rest are tourist months

Reasons companies have chosen jour facility over others and reasons thej return: small size of facility and Aspen location

Where is jour major competition: other rescrts in Aspen, vail ard snowmass. 
Name of Facility: Carson Inn/Nordic Hills Resort/Conference Center Address: Nordic Road, Itasca, Illinois

Contact Person: Carol Brooks, Director of Sales

Distance from Airport: 12 miles from OHare International

Type of Iacility: two ten-story towers housed 220 rooms overlooking a golf course in a wooded setting. Landing pad for helicopters on site.

Sizes of Meeting Rooms: two two-story clubhouses house 25 meeting rooms. Magnum Room, $67 \times 41 \times 15$; 0slo Room, $48 \times 48 \times 18$; تelsinki Room, $47 \times 36 \times 10$; Garden Room, $43 \times 35 \times 10$.

Recreational Amenities: heated indoor and outdoor pool, health club and $8 \mathrm{Jm}$; game room and 6 lane bowling alley. 5 outdoor tennis courts, 8 racquetball courts. 18 hole golf course and jogging traiz.

Rate Structure: European plan, \$37.41 single; $\$ 43-47$ double;

$\$ 50-100$ suites.

was it originally a conference center? Center was designed with large, corporate meetings market in mind to incorporate all things

that corporate meetings need. enough to Chicago, jet has isolation and ambience to put on excelient meetings.

Percentage of business arriving by air, car, etc., and from what section of the country: $75 \%$ of business meeting attendees arrive by air through 0'iare; approx. 25\% drive in from surrounding areas. Meeting attendees come fron Jast Coast as well as Midwest.

Sources of your business: $80 \%$ of business is corporate meetings business; $20 \%$ is transient and racation.

Types of meetings most commonly held at jour facility: professional and technical meetings, new product meetings, government meetings and management meetings.

Average attendance and duration of metings: 5 days, 50 - 70 attinde $\epsilon$

Percentage of repeat business: $80 \%$ of business is repeat

Patterns of weekly and jearly occupancy: Honday - Friday and Thursday - sunday. Only summer months are slower.

Reasons companies have chosen your facility over others and reasons they return: excellent central location and audio-visual capabilities as well as staff.

where is your major competition: other meeting facilities in Chicago and survounding cities. 
Name of Facility: Chauteau Louise Resort and Conference Center Address: Route 31, west Dundee, Illinois

Contact Person: Vaughn Holbert, Director of Sales

Distance from Airport: 22 miles from OHare International Airport Type of Facility: suburban resort hotel consisting of 150 rooms in English Tudor style buildings

Sizes of Meeting Rooms: 21 meeting rooms and 8 parlors; Great Hall $60 \times 121 \times 13$; Tudor Room $70 \times 40 \times 13$; Normandy Room $31 \times 68 \times 8$

Recreational Amenities: glass-domed indoor swimming pool, 2 separate health clubs, 4 outdoor tennis courts, indoor racquet-ball 2 18-hole golf courses and horseback riding 10 minutes away

Rate Structure: European plan, single from $\$ 42$; double from $\$ 52$. Suites $\$ 75-95^{\circ}$

ias it originaliz a conference center? Jotel was turned into a confer ence center by new owners.

Ideas used to make jour facility unique from others: Expertlytrained conference coordination staff and personal touches.

Percentage of business arriving by air, car, etc., and from what section of the country: Most business arrives by limo or car coming from whole Midwest Region and partially from Northeast.

Sources of jour business: $15 \%$ transient, $25 \%$ vacation, $65 \%$ meetings business.

TJpes of meetings most commonly held at your facility: incentive meetings, executive training sessions, medical meetings.

Average attendance and duration of meetings: 30 - 50 persons, 3 days.

Percentage of repeat business: $75 \%$ meetings business is repeat

Patterns of weekly and yearly occupancy: Monday through Inursday are busiest days; however, weekend meetings are increasing.

Reasons companies have chosen your Pacility over others and reasons they return: Excellent resort facilities and location.

where is Jour major competition: other conference facilities around Chicago area. 
Name of Facility: Colonialivilliamsburg Conference Center

Address: villiamsburg, Virginia

Contact Person: Donald Bruce, Director of Sales

Distance from Airport: 30 miles from Richmond's Bird Airport, and 16 miles from Patrick Henry Airport in Newoort News, Virginia. Type of Facility: 735 total guest rooms divided into 3 separate racilities; a 222 room inn, 200 room lodge and 314 room motor house. within walking distance to colonial Williamsburg.

Sizes of Meeting Rooms: 19 total meeting rooms include the Ballroom, Tidewater Room, Cascade Room and Virginia Room.

Recreational Amenities: 4 swimming pools in total, 8 tennis courts 18-hole golf course, driving range.

Rate Structure: European plan, seasonal. Single, $324-49$; double, \$25-53; suites, $\$ 46-144$.

was it originally a conference center? originally 3 tourist faciliti and meetings rooms added in separate wing.

Ideas used to make your facility unique from others: not available

Percentage of business arriving by air, car, etc., and from what section of the country: 50\% of business arrives by car from Jast coast; remainder ties into iashington area and local airports from rest of the country.

Sources of your business: 50\% meetings-related, 50\% tourist

Types of meetings most commonly held at your facility: Iarge sales meetings, government and professional meetings.

Average attendance and duration of meetings: 60-75 persons, 3 days.

Percentage of repeat business: unavailable

Patterns of weeklJ and JearlJ occupancj: summer months almost entirely tourists; 3 pring and fall heavy meetings months.

Reasons companies have chosen jour facility over others and reasons they return: Good ast coast location, ample facilities. 
Name of Facility: Colorado Springs Filton Inn and Conferenca center Address: 505 Popes Bluff Trail, Colorado Springs, Colorado Contact Person: John Giordano, Director of sales

Distance from Airport: 14 miles from Colorado Springs Airport Type of Facility: 126 guest rooms contained in 2 story building, 5 miles from Colorado Springs business district, 15 miles from Pikes Peak.

Sizes of Meeting Rooms: 8 meeting rooms in total; Assay Ballroom, 66 : 33; Tiger Room $27 \times 13$, Falcon Room $24 \times 14$; Suite Room $27 \times 14$.

Recreational Amenities: outdoor heated swimming pool. Other facilities available at nearby country club.

Rate Structure: zuropean plan, seasonal, single p21-39; double \$31-49. Suites $\$ 75-180$.

was it originally a conference center? Combination conference center and rescrt hotel.

Ideas used to make jour facility unique from others: not available

Percentage of business arriving by air, car, etc., and from what section of the country: almost all business arrives by private limo from Denver or local airport. Wostly from west coast.

Sources of jour business: 50\% resort; 20\% transient; $30 \%$ meetings.

Types of meetings most commonly held at jour facility: regional sales meetings, small incentive groups, professional meetings.

Average attendance and duration of meetings: not available

Percentage of repeat business: $50 \%$

Patterns of weekly and Jearly occupancy: spring and fall higher occupancy for business meetings.

Reasons companies have chosen your facilitj over others and reasons they return: Filton reputation and resort location.

where is Jour major competition: other resorts in Rockies 
Name of Facility: Denver Airport Hilton Inn 3 Conference Center Address: I - 70 at Peoria, Denver, Colorado Contact Person: Judy Mayhew, Sales Manager

Distance from Airport: Located 4 miles from Stapleton International Airport

Type of Facility: Low rise building houses 202 rooms.

Sizes of Meeting Rooms: 2 major rooms are divisible into a total of 9 rooms in total.

Recreational Amenities: Heated outdoor swimming pool.

Rate Structure: Furopean plan, Sinele $\$ 33-43$, Louble $\$ 43-53$.

Was it originally a conference center? center is basically a commercial airport hotel.

Ideas used to make your facility unique from others: not availablo

Percentage of business arriving by air, car, etc, and from what section of the country: The majority of meeting attendees arrive through stapleton International Airport. The remainder come from the Denver area.

Sources of your business: 50\% transient, 50\% meetines reiated.

Types of meetings most commonly held at jour facility: rejional sales meetings, government meetings, new product meetings.

Average attendance and duration of mettings: 2-3 days, 30-60 persons.

Percentage of repeat business: not avaizable

Patterns or weekly and jearly occupancy: Yonday - Friday busy days; weekends generally much slower.

Reasons companies have chosen jour facility over others and reasons they return: excellent location and service.

where is Jour major competition: other commercial facilities in Denver area. 
Name of Facility: Dodzertown Conference Center

(Harrison Conference Services)

Address: Nalker Avenue, Vero Beach, Florida

Contact Person: Dave Smith, sales manager

Distance from Airport: 95 miles from Orlando Airport, 35 miles from Melbourne Airport.

Type of Facility: modern villas house 90 rocms spread out over sports complex on 400 acres.

Sizes of Meeting Rooms: 10 meeting rooms in conference wing; Jackie Robinson Room, Gil Hodges Room, Sandy Koufax Room, Don Drysdale Room, Peewee Reese Room.

Recreational Amenities: 4 tennis courts, 27-hole golf course, 2 outdoor swimming pools, health club and gym, josging trails.

Rate Structure: full American plan, seasonal, single $\$ 75-89$; twin, \$110-130.

'was it orizinally a conference center? Facility was and still' is winter home of I.A. Dodzers.

Ideas used to make your facility unique from others: only 90 rooms ard yet facilities are on 400 acres, thus creating no distractions for attendees.

Percentage of business arriving by air, car, etc., and from what section of the country: all business arrives by car or limo from major airports in Florida. Meetings business from whole East coast and southern part of country.

Sources of jour business: 100\% of meetings, no transient business

Types of meetings most commonly held at jour facility: training type meeting and management decision meetings are specialities.

Average attendance and duration of meetings: 5 days, 15-35 persons.

Percentage of repeat business: $90 \%$ repeat business.

Patterns of weekly and yearly occupancy: Monday - Iriday, weekend business increasing steadily.

Reasons companies have chosen jour facility over others and reasons they return: Jarrison name speaks for itself.

Where is jour major competition: none in immediate area. 
Name of Facility: Drake Oakbrook Hotel and Conference Center

Address: York and Cermak Roads, Oakbrook, Illinois

Contact Person: Rolfe Sick, Director of Sales

Distance from Airport: 7 miles from OHare Airport; 6 miles from Midway Airport

Type of Facility: suburban hotel, housing 175 guest rooms on beautiful grounds.

Sizes of Meeting Rooms: 16 meeting rooms in jotal with soundproof walls. The ballroom is $110 \times 38 \times 12$. Garden Room $68 \times 38 \times 12$. Glen Room $58 \times 38 \times 12$ and Terrace Room $110 \times 27 \times 8$.

Recreational Amenities: indoor and outdoor heated pools, 2 tennis courts, 18 hole golf course $1 / 2$ mile from hotel, indoor tennis, racquet ball 1 mile from hotel.

Rate Structure: Buropean plan, single \$40-44; double \$49-53; suites \$5.

was it originally a conference center? Property has developed into a conference center by adding specialized conference staff.

Ideas used to make jour facility unique from others: relatively small size gives it isolation for small meetings.

Percentage of business arriving by air, car, etc., and from what section of the country: majority of business is comming from a radius of 250 miles and much of that is flying into the local airport or 0'Hare. $25 \%$ is driving from the surrounding area. Sources of your business: transient business, 25\%; approximately $75 \%$ meetings business.

Types of meetings most commonly held at your facility: small training meetings, boards of directors meetings and small sales meetings. Average attendance and duration of meetings: 3 days, 25-35 people.

Percentage of repeat business:50\% ofbusiness is repeat.

Patterns of weekly and jearly occupancy: Monday - Viednesday and Tuesday - Friday are peak patterns. Summer months are slow.

Reasons companies have chosen jour facilitj over others and reasons they return: location is far enough out of metropolitan areas to allow for concentration and participation in recreational facilities.

where is your major competition: other meeting facilities in midwest. Example: Chauteau Louise, King Island, etc. 
Name of Facility: DUNFEY HYANNIS RESORT AND CONFERENCE CENTER. Address: West End Circle, Hyannis, Massachusetts. Contact Person: Kay George, Corporate Account Manager Distance from Airport: 7 miles from Barnstable Nunicipal Airport. Type of Facility: 2 story complex with 250 rooms, spread out over large area. A year-round golf resort located in very scenic area of state.

Sizes of Meeting Rooms: 22 meeting rooms in total and 7 conference parlors. Tivoli Room, $127 \times 81 \times 36$; Osterville Room, $86 \times 45 \times 10$; Bass River Room, $54 \times 85 \times 10$ and Hyannisport Room, $47 \times 58 \times 10$. Recreational Amenities: indoor and outdoor swimming pools, complete health spa, indoor and outdoor tennis courts and 18 hole golf course.

Rate Structure: European plan, single from \$33; double from 637 . Parlors from $\$ 70$.

was it originally a conference center? Yes, to cater to small groups that also wanted luxury.

Ideas used to make your facility unique from others: Many of the ideas are patterned after Earrison Conference Centers.

Percentage of business arriving by air, car, etc., and from what section of the country: 60\% of all business flies through Logan Airport or through local airport; remainder from car and bus and limo.

Sources of your business: Vacation business, mainly in July and August and remainder of year 90\% corporate groups, except on weekends when business is more social.

Types of meetings most commonly held at your facility: Medical meetings, smali professional group meetings, training sessions, government meetings.

Average attendance and duration of meetings: 3 nights, 25-35 people.

Percentage of repeat business: Very high, unable to give exact number.

Patterns of weekly and Jearly occupancy: July and August, $95 \%$ tourists; Nay, June, September and october, $90 \%$ corporate meetings. Rest of the months lower $\%$ for corporate meetings.

Reasons companies have chosen youn facility over others and reasons they return: Excellent conference facilities and staff. Resort atmosphere and Cape location.

Where is Jour major competition: Meeting facilities in Boston area and few arcund the Cape. However, other facilities not as complete as DUNFEY. 
Name of Facility: Fairfield Glade Conference Center Address: P.0. Box 1500, Fairfield Glade, Tennessee Contact Person: Jeff Cooper, Convention Service Manager

Distance from Airport: 75 miles from Knoxville International Airport and 120 from Nashville International Airport. Type of Facility: complex of lodges, condominiums and villas making up 325 rcoms. Located on $\$ 2,000$ acres resort in central Tennessee.

Sizes of Meeting Rooms: total of 8 meeting raoms subdivided from lars: rooms, such as conference center, civic center and fireside rooms.

Recreational Amenities: 36-hole golf course, 4 outdoor, 2 indoor tenn: courts, indoor, outcioor heated pools, health club and gim.

Rate Structure: Iuropean plan, seasonal. Single, \$35-45; double, $\$ 40-50$; suites, $\$ 60-80$.

Was it originally a conference center? originally a condominium complex which perfectly fits into the conference center concept.

Ideas used to make your facility unique from others: conference coordination staff is trained to handle all needs of meeting attendees incluaing recreational activites.

Percentage of business arriving by air, car, etc., and from what section of the country: majority of business comes from states locate around Tennessee and cities such as New Orleans, Atlanta, Cleveland, $\epsilon$ Courtesy cars pick up gas at airports mentioned above.

Sources of jour business: Business is evenly split between transient and resort.

Types of meetings most commonly held at jour facility: medium-sized management meetings, training sessions and regular sales meetings.

Average attendance and duration of meetings: 5-7 days, 30-70 people

Percentage of repeat business: total repeat business over 50\%.

Patterns of weekly and JearlJ occupancy: winter and summer months higher for tourists.

Reasons companies have chosen jour facility over others and reasons they return: location is central for many different areas east of Mississippi. Staff is geared to handle small meetings.

Where is jour major competition: major competition is in other resort in Tennessee, North Carolina and Arkansas. 
Name of Facility: Fairfield Mountains Conference Center

Address: Lake Lure, North Carolina

Contact Person: Holly Gibson, Sales Manager

Distance from Airport: 26 miles from Ashville Maricipal Airport.

Type of Facility: cottages and vilias make up 80 rooms on 1200 acres on private lake.

Sizes of Meeting Rooms: 5 meeting rooms are available. Kain Room, Eearth Room, Nol Conference Room, lio.2 Conference foom.

Recreational Amenities: 2 outdoor pools, 18 hole golf course, ariving range, 2 tennis courts, Iishing, water sking, horseback riding.

Rate Structure: European plan, seasonal; single $\$ 25-59$; double, \$40-85; suites, \$60-90.

was it originally a conference center? originally a small, private resort until conference rooms were added.

Ideas used to make jour facility unique from others: only a few minut go on at a time, and facility caters to only small meetings.

Percentage of business arriving by air, car, etc., and from what section of the country: most business arrives by car from surrouniing area or comes from Ashviliz area.

Sources of your business: $75 \%$ is corporate business meetings; $25 \%$ is vacation business, however this fluctuates with the season.

Types of meetings most commonly held at your facility: small government meetings, executive meetings, professional, technical meetings.

Average attendance and duration of meetings: $15-35$ persons, $4-5$ dajs.

Percentage of repeat business: $60 \%$ of business meetings is repeat.

Patterns of weekly and Jearlj occupancy: Jovember - February are onl: slower months. Summer months get higher percentage of tourists.

Reasons companies have chosen jour facility over others and reasons they return: small-size of facility jet large acreage of area and expertise of conference staff.

where is jour major competition: ocher resorts in immediate area. 
Name of Facility: Great Smokies jilton Resort and Conference Center Address: I Hilton Inn Drive, Ashville, North Carolina. Contact Person: Randy Kinder, Sales Manager

Distance from Airport: 15 miles from Ashville Municipal Airport Type of Facility: 280 rooms in rustic-style low-type building containing 3 guest wings.

Sizes of Meeting Rooms: 8 meeting rooms, Great Smoky Room, $140 \mathrm{x}$ $50 \times 11$ divides into 4 rooms; 7 other meeting rooms by number only.

Recreational Amenities: 18 hole golf course, 4 tennis courts, 4 indoc courts, 2 outdoor swimming pools, saunas.

Rate Structure: European plan, seasonal $\$ 22-39$ and couble, $\$ 30-42$. was it originally a conference center? Divised as a combination resort and commercial conference center.

Ideas used to make your facility unique from others: combination of resort atmosphere and excellent conference center facilities.

Percentage of business arriving by air, car, etc., and from what section of the country: $80 \%$ from local airport; $20 \%$ by car. $75 \%$ of all business comes from a 400-mile radius.

Sources of jour business: $65 \%$ meetings; $20 \%$ vacation; $15 \%$ transient.

Types of meetings most commonly held at jour facility: general sales meetings, educational seminars, incentive meetings.

Average attendance and duration of meetings: 40-50 people; 3 days.

Percentage of repeat business: $65 \%$ corporate

Patterns of weekly and JearlJ occupancy: Konday-Nednesday, busiest days of week. All months except summer months busy with meetings

Reasons companies have chosen Jour facility over others and reasons they return: Good, centralized location, excellent facilities.

where is jour major competition: other resorts in mennessee, yest Virginia and North Carolina. 
Name of Facility: The Greenbrier

Address: white Sulphur Springs, west Virginia

Contact Person: P.iv. Klpp, Director of Marketing

Distance from Airport: 12 miles to Greenbrier Valley Airport and 70 miles to woodrum Field in Roanoke, Jirginia.

Type of Facility: 688 rooms are located on 6500 acres in the Allegheny Mountains. Rooms are in a complex of 19 th century building and a 6 story main building.

Sizes of Meeting Rooms: 30 meeting rooms. Colonial Hall $112 \times 135 \times$ 22, Chesapeake Hall $72 \times 72 \times 22$, Eisenhower $60 \times 90 \times 11$, and Crystal $41 \times 72 \times 19$

Recreational Amenities: heated indoor and outdoor pools, 15 tennis courts, 3 l8-hole golf courses, bowling alley, horseback riding, trap and skeet shooting and carriage rides.

Rate Structure: modified American plan, single $\$ 70$, double, $\$ 65$ per person.

Was it originally a conference center? originally designed as a resort for the rich and due to its elegance and facilities and location, it is also a conference center.

Ideas used to make Jour facility unique from others: idea is to get meeting attendees into the relaxed atmosphere that Greenbrier offers. The reputation of this facility is unique in itself.

Percentage of business arriving by air, car, etc., and from what section of the country: $25 \%$ of guests arrive by chartered flizhts or busses; $25 \%$ rly into major surrounding airports; $25 \%$ take own transportation and up to $25 \%$ take the train. Come from all areas, primarily East of the Missis issippis. $40 \%$ business meetings.

Types of meetings most commonly held at jour facility: many incentive type meetings held, training sessions, government meeting and small professional meetings.

Average attendance and duration of meetings: meetings usually last 5 days with attendance 40-60 persons.

Percentage of repeat business: $90 \%$ vacation business is rajeat and $00 \%$ meetings business is repeat.

Patterns of weekly and Jearly occupancj: April - October are peak periocis for the entire facility.

Reasons companies have chosen your facility over others and reascns the return: The Greenbrier is so unique that a meeting in its setting sets a special tone that allows important business to be accomplished.

where is your major competition: no major competition. 
Name of Facility: Garrison Conference Center of Glen Cove Address: Doscris Lane, Glen Cove, New York

Contact Person: James Barry, Regional Sales Office

Distance from Airport: 20 miles from JFr International and La Guardia.

Type of Facility: 133 guest rooms housed in 2 guest wings. Main house is old Georgian manor on 55 acre country estate overlooking Long Island Sound.

Sizes of Meeting Rooms: 25 meeting roons located throughout facility. Embassy Rocm, 50 x 50; Naussau and Suffolk rooms, 22 $x$ 84; the Forum, $27 \times 54$; Oak Room, $24 \times 43$.

Recreational Amenities: 2 outdoor swimming pools ( 1 is heated), 2 lighted tennis courts, 2 lane bowling alley, health spa and EJM. 18 hole jolf course within 5 minute drive.

Rate Structure: full American plan, single $\$ 105$; double $\$ 160$.

Was it originally a conference center? Jarrison Conference Services converted this mansion to their first conference center

Ideas used to make your facility unique from others: Harrison conference Center ideas.

Percentage of business arriving by air, car, etc., and from what section of the country: majority of business coming from 4state area surrounding center.

Sources of your business: 100\% business meetings

Types of meetings most commonly held at jour facility: training meetings and sales meetings; management development meetings.

Average attendance and duration of meetings: 15 to 30 persons;
3 to 5 days.

Percentage of repeat business: $90 \%$

Patterns of weekly and Jearly occupancy: see report

Reasons companies have chosen jour facility over others and reasons they return: Jarrison name 
Name of Facility: Earrison Conference Center of Heritage Village Address: The Village Green, Feritage Village, Jouthbury, Connecticut Contact Person: Ted McCallum, Assistant Sales Manager

Distance from Airport: 90 miles north of New York, 35 north of Bradley International Airport, Hartford.

Type of Facility: 121 guest rooms in rustic buildings.

Sizes of Meeting Rooms: 20 meeting rooms in separate 2-story wing. The Lincoln Room, $32 \times 74$; Madison and Jefferson Room, $27 \times 40$; Grant Room, $32 \times 20$ and Jackson, Washington, Roosevelt, Eamilton, 20 Recreational Amenities: heated outdoon swimming pool, health club with gym, billiard room, 2 lighted tennis courts, 13-hole golf course.

Rate Structure: Full American plan, single ilo5; double 3158;

Was it originally a conference center? originally part of condominium development; guest rooms used to house potential buyers ised to make your facility unique from others: ideas of Farrison Coniezence Services.

Percentage of business arriving by air, car, etc., and from what section of the country: 50\% of meeting attendees arrive from Metropolitan area of New York. Remainder of guests flown in from East coast and rest of country.

Sources of your business: $100 \%$ corporate meetings.

Types of meetings most commonly held at jour facility: training meetiags and management meetings

Average attendance and duration of mettings: 15-30 persons, 4 days.

Percentage of repeat business: $90 \%$ repeat business Patterns of weekly and Jearly occupancy: see report

Reasons companies have chosen your facility over others and reasons they return: Harrison name

where is your major competition: none in immediate area. 
Name of Facility: Farrison Conference Center of Lake Bluff

Address: Green Bay Road, Lake Bluff, Illinois

Contact Person: Daniel OMalley, General Manager

Distance from Airport: 30 minutes from 0 Hare Airport.

Type of Facility: 130-acre estate, 3-story Mediterranean Villa with 84 guest rooms.

Sizes of Meeting Rooms: 11 meeting rooms; Great Eal1, $35 \times 70 \times 53$; Iunt Room, $35 \times 45 \times 16$; Marble Room $25 \times 35 \times 16$; Library, $24 \times$ $41 \times 12$.

Recreational Amenities: cutdoor heated swimming pool, all lawn sports and golf driving range. 2 tennis courts, 5 minutes from 2 golf courses.

Rate Structure: full American plan, single $\$ 96$; twin $\$ 138$.

was it originally a conference center? former estate converted into conference conter.

Ideas used to make your facility unique from others: ideas of Harrison Conference Services.

Percentage of business arriving by air, car, etc., and from what section of the country: majority of business comes from Micwest areas, specifically Chicazo. However, companies from all U.S. fly people in.

Sources of your business: $200 \%$ corporate meetings

Types of meetings most commonly held at jour facility: training type meetings and management decision meetings.

Average attendance and duration of meetings: 15-30 people, 4 days.

Percentage of repeat business: 90\% repeat business

Patterns of weekly and Jearly occupancy: Monday throuzh Friday (see report) with weekend business increasing.

Reasons companies have chosen your facility over others and reasons the return: Earrison name

where is jour major competition: none in immediate area 
Name of Facility: Hilton Larvest House Resort and Gonference Center Address: 134528 th Street, Boulder, Colorado Contact Person: Jan Intine, Sales Representative

Distance from Airport: 30 miles from Stapleton International Airport, Denver

Type of Facility: high-rise hotel containing 286 rooms, located in the center of Boulder, Colorado.

Sizes of Meeting Rooms: 9 meeting rooms which include Grand Ball Room which can be further broken down; Grand Eall Room, $84 \mathrm{x} 66$; Centr Room, $70 \times 25$; Canyon Room, $35 \times 34$; Flagstaff Room, $35 \times 33$

Recreational Amenities: 5 heated pools, 11 racquetball courts, healt club and gym, 15 tennis courts, jogging trail.

Rate Structure: European plan, single \$33-40; double \$41-40; suite, $\$ 90$ and up.

was it originally a conference center? designed as a combination midtown and resort hotel with special emphasis for meotings.

Ideas used to make your facility unique from others: not available

Percentage of business arriving by air, car, etc., and from what section of the country: $75 \%$ of all buwiness arrives through Denver area; remainder takes alternative forms of transportation - cars, busses, etc.

Sources of jour business: $30 \%$ resort, $70 \%$ transient or meetings business.

Types of meetings most commonly held at your facility: regional sales meetings, medical meetings, proiessional and technical meetings.

Average attendance and duration of meetings: 50 to $75,3-4$ days

Percentage of repeat business: 50\% of meetings business is repeat

Patterns of weekly and JearlJ occupancy: winter months slower for business meetings but high for resort business. weekends generally slower for meetings.

Reasons companies have chosen jour facilit over others and reasons they return: location far enough out of Denvar to offer isolation yet sood locations. Staff is well-trained in conference coordination. and Vail. 
Name of Facility: THE HILTON INN AND CONFERENCE CENTER

Address: 1901 University 3lvd., Albuqerque, New Mexico

Contact Person: Mark Stein, Director of Sales

Distance from Airport: 7 miles from Sunport Airport

Type of Facility: midtown hotel, consisting of 12 story building housing 462 guest rooms. Outside-type rooms are villas and cabanas.

Sizes of Meeting Rooms: international room, $82 \times 95 \times 96$. Nediterranean Room, $96 \times 48 \times 16$. Garden Room, $40 \times 40 \times 16$. Civic Room, $40 \times 40 \times 14$. 25 meeting rooms in total.

Recreational Amenities: heated outdoor and indoor pool, health spa, two tennis courts and skiing nearby.

Rate Structure: Zuropean plan, single \$30-39; double $\$ 38-47$. Suites $\$ 75-175$.

was it originally a conference center? Designed as a midtown luxury hotel to cater to all types of meetings.

Ideas used to make jour facility unique from others: combines two worlds of downtown and resort-type atmospheres.

Percentage of business arriving by air, car, etc., and from what section of the country: 65\% of total meeting attendees arrive by air; $30 \%$ by car. Majority arrive from Pacific states and entire Southeast section. Certain groups from Texas and Mexico.

Sources of jour business: 30\% tourist and travellers; $10 \%$ transient; $60 \%$ business meetings.

Types of meetings most commonly held at your facility: regional salt meetings, management meetings, small incentive meetings.

Average attendance and duration of meetings: 3 days; approximately 50 people.

Percentage of repeat business: $65 \%$

Patterns of weekly and Jearly occupancy: Monday - Thursday; Friday . sunday. Only slow times of the year are July and August and December and January, for corporate meetings.

Reasons companies have chosen your facility over others and reascns they return: Easy access of location and many different types of meeting facilities.

where is jour major competition: Resorts on outskirts of city and hotels and resorts in Phoenix and Tucson. 
Name of Facility: Filton Inn and Conference Center at Inverrary

Address: 3501 Inverrary Blvd, Ft. Lauderdale, Florida

Contact Person: Art Cohen, Direct of Sales and Marketing

Distance from Airport: 22 miles to Ft. Lauderdale International Airport; 35 miles from Miami International Airport

Type of Facility: 209 rooms in an 8-story, modern buildine, located in the suburbs of Ft. Lauderdale.

Sizes of Meeting Rooms: 12 meeting rooms are on 1 floor in a separate wing. Biscayne and Inverrary Roor, Now England and Empire Room are 48 × 32 × 12; Capital and Great Lakes Room, Niagara Rooms Recreational Amenities: Outdoor swimming pool, health club with 8Jm, golf course and driving ranges, 30 tennis courts

Rate Structure: American plan, seasonal, single from $\$ 90$; double from $\$ 70$ per person.

Was it originally a conference center? Specifically designed to cater to corporate meetings.

Ideas used to make your facility unique from others: relaxed atmosphere with plenty of recreation with high-quality meeting rooms and audio=visual capabilitiss.

Percentage of business arriving by air, car, etc., and from what section of the country: Conference center just opened up in early 1979; figures not available.

Scurces of jour business: early indications show many meetings held by international companies and from comparies located along eastern seaboard.

Types of meetings most commonly held at your facility: no data available as jet.

Average attendance and duration of meetings: no data available at present.

Percentage of repeat business: no data available at present. Patterns of weekly and jearly occupancy: no data available at present

Reasons companies have chosen jour facility over others and reasons they return: superior audio-visual capabilities and excellent location, especially for winter meetings.

where is jour major competition: a few of the better resorts in the stat: of Florida. 
Name of Facility: Hilton Shanty Creek Resort and Conference center Address: P.0. Zox 355, Bellaire, Michigan

Contact Person: Pat Savant, Director of Sales

Distance from Airport: 35 miles nortin of cherry County Airport in Iraverse City, approx. $200 \mathrm{miles}$ north of Detroit and chicago. Type of Facility: 123 total guest rooms located in modern, 1odgetype buildings on 1282 acres of natural woodlands bordering on

Lake Michigan.

Sizes of Meeting Rooms: 3 meeting rooms divided into 6, the Belaire Room, $110 \mathrm{x} 46$; Top Deck Room, $34 \mathrm{x} 50$ (east and west), Founders Room, $35 \times 30$.

Recreational Amenities: heated outdoor pool, 350 private beach, 2 tennis courts, 18-hole golf course and sking narby.

Rate Structure: European plan, seasonal (Amerioan plan arailable) single, p30-55; double, 335-60; Suites, 357-90.

was it originally a conference center? desiened to be a resort and conference center.

Ideas used to make your facility unique from others: seclusion needed and recreational amenities necessary

Percentage of business arriving bJ air, car, etc., and from what section of the country: much of business arrives through small, local airports in area. Remainder of business takes limos and private cars from Lansing, Michigan, Grand Rapids and Flint.

Sources of your business: summer and winter, $75 \%$ vacation business. kest of year percent is approx. 50-50.

Types of meetings most commonly held at your facility: small incentiv meetings, training and executive meetings.

Average attendance and duration of meetings: 5 days, 35 people

Percentage of repeat business: $60 \%$ vacation business, $40 \%$ meetings business is repeat.

Patterns of weekly and yearly occupancy: see above

Reasons companies have chosen your Pacility over others and roasons they neturn: Filton name and necessary seclusion of facizities; special staff treatment.

where is Jour major competition: none in above area. 
Name of Facility: Holiday Inn Executive Conference Center

Address: 11200 E. Goodman Road, Olive Branch, Nississippi

Contact Person: Tom Johnson, General Nianager

Distance from Airport: 15 miles south of Memphis International Airport.

Type of Facility: 175 rooms situated on 88 acres with a private lake. The 4 story building is of the modern school of architecture. The facility is isolated from the congestion of the big city but close enough for good connections.

Sizes of Meeting Rooms: 16 meeting rooms in total. Grand Fall $35 \mathrm{x}$ $72 \times 12,6$ classrooms are $26 \times 25 \times 12,4$ meeting rooms are $18 \times 24$ $x 8$ and 4 conference rooms are $18 \times 18 \times 12$.

Recreational Amenities: Heated outdor pool, private lake for fishing, 18 hole golf course, 4 lighted tennis courts, health spa and game room.

Rate Structure: American Plan, Single $\$ 55$, Double $\$ 90$ and a Suite for 1 or 2 people $\$ 89-150$.

was it originally a conference center? Center was originaliy Folidays Inns training site for it's management training and was being only partially used. Facility was originally designed for teaching and training it is perfect for meetings that need top notch audio visual equipment.

Percentage of business arriving by air, car, etc., and from what section of the country: Center was only converted to a full time conference center less than a year ago so many facts are incomplete.

Sources of your business: The center is aiming at a certain percentage of usage by the Holiday Inn Company and the rest will be the corporate meetings market.

Types of meetings most commoniy held at your facility: Center is attempting to concentrate on training meetings or all types, and sales type meetings

Average attandance and duration of meetings: Not available yet.

Percentage of repeat business: They are looking at a figure of over $80, \%$

Patterns of weekly and Jearly occupancy: Although Nonday through Thursday will be the busy periods for meetings, the center will try to book more weekend meetings.

Reasons companies have chosen jour Pacility over others and reasons they return: Excellent audio visual facilities, and staff to back them up. Excelient mid country location and connections in remphis.

Where is jour major competition: None in immediate area. 
Name of Facility: The Fomestead

Address: Hot Springs, Virginia

Contact Person: Sam Zabawsky

Distance from Airport: 75 miles from Roanoke, Virginia, Hoodrum Field Airport; 17 miles from Ingalls Field Airport

Type of Facility: Georgian-style hotel containing 694 rooms in a main building and cottages. Located on 16,000 acres in the heart of Virginia Alleghenys.

Sizes of Meeting Rooms: 25 meeting rooms in the main building and conference complex. Commonwealth Room, $85 \times 85$; Conference Center Room, $128 \times 83$; Empire room, $91 \times 34 ; 4$ rooms each $19 \times 31$.

Recreational Amenities: $3-18$ hole golf courses, 15 tennis courts, heated outdoor and indoor pool, fishing, horseback riding, skeet and trap shooting, skiing and ice skating.

Rate Structure: American plan, single \$68-88; double $3136-144$; special low rates iovember to March.

was it originally a conference center? originally a resort for the rich.

Ileas used to make your facility unique from others: All the ameniti of a luxury resort combined with expertise of meeting staff.

Percentage of business arriving by air, car, etc., and from what section of the country: Most business arriyss by private limo or car. Meeting attendees come from 211 over East coast and ridwest.

Sources of your business: 'Seasonal, on the average approximately $65 \%$; 35 ; weetings related.

Types of meetings most commonly held at jour facility: National sales meetings, regional sales meetings, large association meetings, week-long training meetings.

Average attendance and duration of metings: 75 to $100,5-7$ dajs.

Percentage of repeat business: 75\% vacation business repeat; $50 \%$ of meetings business is repeat.

Patterns of weekly and Jearly occupancy: November-Narch betten meeting months; rest of the year has higher $;$ of resort guests.

Reasons companies have chosen Jour Facility over others and reascns they return: reputation of very high quality facility

where is jour major competition: the Greenbrier. 
Name of Facility: Howard Johnson's O'Hare International Hotel and Conference Center

Address: 10249 west Irving Park Road, Schiller Park, O'Hare Airport Chicago, Illinois.

Contact Person: A. Shaikh, General Manager ic Director of Sales

Distance from Airport: situated on southeast corner of olHare airport and 3 minutes from all terminals.

Type of Facility: airport hotal with 7-story ultramodern hotel house $300^{\circ}$ guest rooms. 13 miles from downtown Chicago.

Sizes of Meeting Rooms: 13 meeting rooms. International Ballroom, $83 \times 55 \times 17$; Court Room, $51 \times 23$ x 16; 4 rooms each, $29 \times 28 \times 9$ and 4 rooms each, $25 \times 16 \times 9$.

Recreational Amenities: heated indoor pool and 1 wading pool. Fealt: exercise club with two saunas.

Rate Structure: Year-round, European plan, single 948 and up; doubl. $\$ 58$ and up; suites $\$ 95$ and up.

Was it originally a conference center? Designed to be an airport hotel that would cater to the corporate meetings market.

Ideas used to make your facility unique from others: hotel is situa. on airport site and Jet the atmosphere seems like a conference cente Audio visual capabilities are excellent and staff is trained in all area of meetings expertise.

Percentage of business arriving by air, car, etc., and from what section of the country: 75\% of meeting attendees arrive trrough o'Hare and the other $25 \%$ drive in from surrounding areas.

Sources of Jour business: $50 \%$ of meetings business is transient; $50 \%$ is meetings business

Types of meetings most commonly held at jour facility: regional sales meetings, new product meetings, short sales meetings.

Average attendance and duration of meetings: 40 to 50 persons, 2 days.

percentage of repeat business: unable to provide information.

Patterns of weekly and jearly occupancy: Monday - Vednesday, Viednesday - Iriday, Thursday - Saturday. Business slower in summer months.

Reasons companies have chosen jour facility over others and reasons they return: location, staff and facilities

where is jour major competition: conference-center type meetinj racilities in area. 
Name of Facility: Indian Rock Resort and Conference Center Address: P.0. Box 300F, Fairfield Bay, Arkansas

Contact Person: Richard Lumsden, Director of Sales

Distance from Airport: 80 Northeast of Little Rock Airport

Type of Facility: large resort-type complex, spread out over 1000 acres.

Sizes of Meeting Rooms: total number of meeting rooms is 14 . However no other iaformation was sent.

Recreational Amenities: large, private lake has beach, boating, fishing and water sports. Golf course, health club, outdoor pool and tennis courts.

Rate Structure: singles from $\$ 47$; doubles from $\$ 51$.

Was it originally a conference center? No, originally designed as resort with conference idea catching on later.

Ideas used to make jour facility unique from others: seclusion, full amenities for all meetings.

Percentage of business arriving by air, car, etc., and from what section of the country: 50\% travel into little Rock airport and take shuttle to facilitz; remainder takes private cars or private planes from areas such as Texas, Oklahoma, Tennessee, Kentucky, Ohio, sotches of jour business: summer is all vacation; remainder of month. are 50-50 mixture of vacationers and company meetings.

Types of meetings most commonly held at jour facility: large sales meetings, training meetings, large management meetings.

Average attendance and duration of meetings: 40 - 65 people; 45 days.

Percentage of repeat business: $80 \%$ vacation; $50 \%$ corporate

Fatterns of weeklJ and JearlJ occupancy: Monday through Thursday busiost days of week; heavy business months are Maroh, April, May September, october.

Reasons companies have chosen jour facility over others and reasons they return: size of facility enables each group to have privacy and central location of facility.

where is jour major competition: none in immediate area 
Name of Facility: Kings Island Inn Conference Center

Address: 5691 Kings Island Drive, Mason, Ohio.

Contact Person: Guy 3ising, Seles Nanager

Distance from Airport: 35 north of Cincinnati Airport

Type of Facility: 285 rooms in 6-story building. Suburban-type facility.

Sizes of Meeting Rooms: 6 meeting rooms in total.

Recreational Amenities: 6 tennis courts, outdoor pool, game room, golf course nearby.

Rate Structure: Jurcpean plan, rates unavailable.

'was it originally a conference center? originally a suburban motel which was turned into conference center with addition of meeting usooms to make jour facility unique from others: unavailable

Percentage of business arriving by air, car, etc., and from what section of the country: majority of business from Ohio, Indiana Kentucky, Pennsylvania. Majority drive in from surrounding areas, mentioned above.

Sources of your business: $40 \%$ transient, $40 \%$ business related, $20 \%$ resort and vacation.

Types of meetings most commonly held at jour facility: regional sale meetings, small training sessions, management meetings.

Average attendance and duration of meetings: 3 days, 25-40 persons

Percentage of repeat business: unavailable

Fatterns of weekly and jearly occupancy: Monday-Thursday heavy time December-February slower meeting times.

Reasons companies have chosen your facility over others and reasons they return: central geographic location, excellent facilities.

where is jour major competition: other conference facilities in Ohio, Illinois. 
Name of Facility: Lion Square Lodge \& Conference Center

Address: F.0. Box 2339, Vail, Colorado

Contact Person: Sam Madden, Convention Services vianager

Distance from Airport: 110 miles from Stapleton International Airport; 10 mizes from Vail's livon Airport

Type of Pacility: 160 rooms, most of which in condominiums, 4 blocks from Vail Village, overlooking Gore Creek.

Sizes of Meeting Rooms: portable walls provide for 6 meeting rooms Gore Creek East and west, Downhill, Downhill Slalom, Downhill Free Style.

Recreational Amenities: 2 outdoor heated swimming pools, 8 tennis courts and golf course are $1 / 2$ mile away in Vail Municipal golf course. Skiing and hiking in season

Rate Structure: European plan, seasonal; single $\$ 30-50$; double \$36-55; suites $\$ 100-200$.

was it originally a conference center? originally a concominium development with neeting rooms added.

Ideas used to make jour facility unique from others: not availabls

Percentage of business arriving by air, car, etc., and from what section of the country: most business arrives from local airport or bus or Iimo from Denver. Coming from entire west Coast and some from East Coast.

Sources of your business: fall and spring, $50 \%$ business meetings rest of the year much less.

Types of meetings most commonly held at jour facility: government meetings, small management training meetings.

Average attendance and duration of meetings: 15 - 30 persons, 4-5 days.

Percentage of repeat business: unable to provide information.

Patterns of weekly and jearlJ occupancy: fall and spring businest meetings month; rest are heaviest tourists months.

Reasons companies have chosen jour facility over others and reasons they return: serenity of surroundings, budget prices for facilities

where is jour major competition: similar resort and conference centers throughout Rockies. 
Name of Facility: National Conference Center

Address: Nonmouth street, East Nindsor, New Jersey

Contact Person: Coleman Finkel, Executive Director

Distance from Airport: 35 miles from liewark International Airport

Type of Facility: commersial type of facility with 209 guest rooms attached in a local Filton.

Sizes of Meeting Rooms: total number, 23.

Recreational Amenities: game room, golf, pool, sauna and tennis

Rate Structure: unavailable

Was it originally a conference center? specifically desizned for that purpose.

Ideas used to make jour facility unique from others: highest quality audio-visual and conference staff available.

Percentage of business arriving by air, car, etc., and from what section of the country: $75 \%$ of business comes from East coast companies; those meeting attendees not living in N. $v$. metropolitan area flown in by companies.

Sources of your business: $\quad 100 \%$ corporate meetings business

Types of meetings most commonly held at jour facility: training meetings, sales meetings, executive decision meetings.

Average attendance and duration of meetings: 3-5 days, 35-50 people.

Percentage of repeat business: $75 \%$

Fatterns of weekly and gearly occupancy: Mondafiecnesiay, TuesiajFriday. All months heavy, except vacation periods.

Reasons companies have chosen jour facilitj over others and reasons they return: well-known reputation.

where is jour major competition: cther conference centers on East Coas: 
Name of Facility: Otter Crest Resort and Conference Center Address: P.O. Box 50, Otter Rock, Oregon

Contact Person: Bonnie Holly, director of sales

Distance from Airport: 30 minutes from Newport Wunicipal Aipport

Type of Facility: low-rise lodges house 300 rocms on blufi surrounded by ocean

Sizes of Meeting Rooms: separate conference wing houses 5 meetins rooms. Conference Center meeting room, $75 \mathrm{x} 120$; Room $\mathrm{A}, \mathrm{B}$, and $\mathrm{C}$ $25 \times 40$.

Recreational Amenities: heated outdoor pool, private beach, 2 tennis courts, fishing, golf at nearby country club.

Rate Structure: Iurcpean plan, single $\$ 35-40$; double $\$ 40-45$; suites Q75-100.

was it originally a conference center? originally a resort

Idess used to make your facility unique from others: located on bluff.

Percentage of business arriving by air, car, etc., and from what section of the country: $90 \%$ business arrives by limo or private car, from west coast

Sources of jour business: $70 \%$ resort, $30 \%$ business

Types of meetings most commonly held at jour facility: incentive meetings, zovernment and professional meetings.

Average attendance and duration of meetings: 60-75 people; 5-7 dajs

Percentage of repeat business: not available

Patterns of weeklJ and jearlJ occupancy: October-iarch businest meeting months.

Reasons companies have chosen jour iacility over others and reasons they return: beautiful, secluded location, expert conference starf

where is your major competition: none in surrounding area 
Name of Facility: Pajaro Dunes Conference Center

Address: 2661 Beach Road, Watsonville, California

Contact Person: Marylou Daw, sales manager

Distance Prom Airport: 25 miles from Monterrey Airport, 35 miles from San Jose Airport, 73 miies from San Francisco International Airpo Type of Facility: 143 modern condominiums with from 1 to 6 be irooms totaling 360 rooms on 150 acres on stretch of beach on Nonterrey 3ay.

Sizes of Meeting Rooms: larger, condominium living areas can accommodate small, Group meetings. Other meeting rooms are South ral1, $40 \times 30 \times 12$, Cyprus, $40 \times 56 \times 12$ and Lagoon, $44 \times 65 \times 12$,

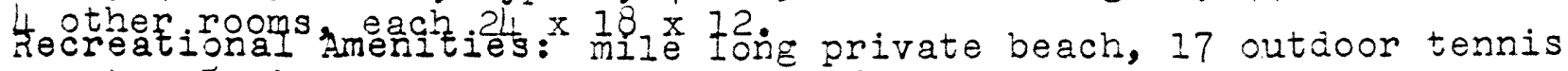
courts, 5 miles to Pajaro Vallay Golf Course.

Rate Structure: American Plan, single \$55 - 80; couble, \$100-130.

Nas it originally a conference center? Was criginally a condominium vacation center.

Ideas used to make your facility unique from others: Meetings are isolated enough ror total seclusion, Jet provisions are made for all meeting needs.

Percentage of business arriving by air, car, etc., and from what section of the country: Most all business must drive in from either Los Angeles or San Francisco or fly in from local airport.

Veetings are coming from entire Pacific Coast, Hawaii and ridwest.

Sources of jour business: $75 \%$ vacation and $25 \%$ meetings on the avaerage. Fizures vary during summer month and winter months.

Types of meetings most commonly held at your facility: small training meetings. Top level management decision meetings.

Average attendance and duration of meetings: 5 dajs and 25 people

Percentage of repeat business: $75 \%$ of all meetings business is repeat and $90 \%$ of all vacation business is repeat. Patterns of weekly and jearly occupancy: See above figures

Reasons companies have chosen jour facility over others and reasons they return: Isolation for important meetings and beauty of facilitj.

where is jour major competition: Other facilities on Nonterey peninsula. 
Name of Facility: Prospector Square Ski and Conference Center Address: P.0. Box 1698, Park City, Utah

Contact Person: Janet Casey, Sales Manager

Distance from Airport: 30 miles from Salt Lake City International Airport

Trpe of Facility: 31 guest rooms with kitchenettes in a 2-story building, located in middle of Park City ski area.

Sizes of Meeting Rooms: 14 meeting rooms. Prospector Theater, $85 \mathrm{x}$ 50; Silver King Rooms, (4 rooms), $80 \times 30 \times 9$; Coalition Rooms (4) $30 \times 20 \times 9$.

Recreational Amenities: full athletic club and heated pool, 4 racquet ball courts; skiing, golf and tennis located nearby; backpacking, water skiing, boating and fishing nearby.

Rate Structure: European plan, seasonal; single $\$ 24$ - 34; double $\$ 28$ - 39.

was it originally a conference center? Originally designed as a ski resort and then meeting rooms added.

Ideas used to make your facility unique from others: Neeting supports systems.

Percentage of business arriving by air, car, etc., and from what section of the country: Most business flies into salt lake City and arrives by car or limo. Most business coming from ivest ccast, growing amounts coming from Midwest.

Sources of your business: vacation business accounts for $50 \%$ while meetings business is $40 \%$ and growing. Winter season is $95 \%$ vacation.

Types of meetings most commonly held at jour facility: incentive meetings, large sales meetings, large association meetings.

Average attendance and duration of metings: 5 days, 50-100 persons.

Percentage of repeat business: $35 \%$ of meetings business is repeat, $75 \%$ vacation.

Patterns of weekly and gearly occupancy: Monday through Thursday and Thursciay - jidnday.

Reasons companies have chosen jour facility over others and reascns they return: Ski resort atmosphere, recreational facilities in the area and staff.

where is your major competition: other ski resorts in Utah and Colorado. 
Name of Facility: Provincetown Inn \& Executive Conference Center Address: Commercial St, P.0. Box 619, Frovincetown, Massachusetts. Contact Person: Brooke Evans, Owner

Distance from Airport: 5 miles from Provincetown Airport.

Type of Facility: 102 rooms in a motel layout with colonial style building. Resort atmosphere at tip of the cape on the water with private beaches. One mile from city of Provincetown.

Sizes of Meeting Rooms: 6 meeting rooms with two of them capable I' being divided into three sections each. Tiffany $67 \times 64 \times 10$, Mayflower $91 \times 36 \times 12$, Four and Aft $49 \times 30 \times 12$, Trawler $25 \times 18 \times 1$

Recreational Amenities: Indoor swimming pool, 5 tennis courts,Sailing, boating and fishing, 7 miles to Golf club.

Rate Structure: European plan, Seasonal, Single from $\$ 28-66$, Double 36-72. Suite rates on special request.

was it originally a conference center? Originally a seasonal resort untill conference room were added and then conference center concept was developed.

Ideas used to make jour facility unique from others: Combine the

beautiful resort atmosphere with a small facility with the expertise to handle small meetings.

Percentage of business arriving by air, car, etc., and from what section of the country: Most guests arrive by car or special limo from Boston area. Guest and companies are from all over the Northeast and Great Lakes region of the country.

Sources of Jour business: Summer month and holidays are heavey with vacation business, rest of the year $65 \%$ meetings business.

Types of meetings most commonly held at jour facility: Medical meetinss, small. incentive meetings and some association business.

Average attendance and duration of meetings: $25-35$ people for 3 days. (approx.)

Percentage of repeat business: $90 \%$ vacation, $50 \%$ meetings.

Patterns of weekly and Jearly occupancy: Monday through Thurdays for business meetings and heavey meetings months are March, April October and November.

Keasons companies have chosen jour facility over others and reascns the return: secluded location and small size of facility

where is jour major competition: Other small resort on the coast. 
Name of Facility: Pheasant Run

Address: North Avenue, St. Charles, Illinois

Contact Person: Denny Carlstedt, Director of sales

Distance from Airport: 28 miles from OlHare National Airport facility has own helicopter pad.

Type of Facility: 278 rooms in 2-story rustic lodge, located on 300 acres in Fox River Valley.

Sizes of Meeting Rooms: total of 33 meeting rooms located in main building and convention building. Fresident Room, $40 \times 100$; New Orleans Room, $70 \times 85$; Fayloft Room, $28 \times 100$; Rembrandt Room, Recreational Amenities: indoor and cutdoor heated pool, health club and EJm, 4 indoor and 9 outcoor tennis courts, 2 18-hole golf courses.

Rate Structure: Juropean plan, single $832-46$; double $\$ 46-56$.

Was it originally a conference center? originally a suburban resort transformed into a conference center.

Ideas used to make your facility unique from others: unavailable

Percentage of business arriving by air, car, etc., and from what section of the country: large majority from companies in Chicaso area who fly in people to their headquarters.

Sources of jour business: $75 \%$ meetings related; $25 \%$ transient and resort.

Types of meetings most commonly held at your facility: regional sales meetings, corporate management meetings and training meetings.

Average attendance and duration of meetings: 4 days; 40 persons

Percentage of repeat business: $50 \%$ of meetings business

Patterns of weekly and Jearly occupancy: Monday-Thursday, slower months are july and August and December.

keasons companies have chosen your racility over others and reasons they return: location to chicaso area and lacilities 


\section{CONFERENCE CENTER SURVEY}

Name of Facility: Ramada Inn-Metro Meeting Center

Address: 100 East River Drive, Hartford, Connecticut

Contact Person: Paul Eerquist, Director of Sales

Distance Prom Airport: 15 miles from Bradley International Airport

Type of Facility: suburban hotel 1 mile from lartford Business cente: 8 story hotel houses 215 rooms.

Sizes of Meeting Rooms: 7 meeting room suites and 4 meeting rooms on the first floor. Grand $3 a l l$ Room, Vendome Room, LaConcorde Room, Montmarte Room, I Itoile Room and convention area.

Recreational Amenities: indoor heated swiming pool, health spa.

Rate Structure: Eurcpean plan, single $930-32$; double $36-10$;

Suites $\$ 75$ up.

was it originally a conference center? designed as combination commercial hotel and meeting center.

Ideas used to make jour facility unique from others: not availabl

Percentage of business arriving by air, car, etc., and from what section of the country: $75 \%$ of guests from Greater liew York, iew Jersey, Connecticut areas. Remainder from East Coast and Midwest ?ly in.

Sources of jour business: $75 \%$ meetings related, $25 \%$ transient.

Types of meetings most commonly held at jour facility: regional sales meetings, training sessions, management meetings.

Average attendance and duration of meetings: not available.

Percentage of repeat business: $35 \%$

Patterns of weekly and jearlj occupancy: Monday - Friday pattern of typical commercial hotel.

Reasons companies have chosen jour :acilitj over others and reascns they return: centralized location and more than adequate pacilities. 
Name of Facility: Red Apple Inn and Executive Conference Center Address: Zden Isle, Jeber Springs, Arliansas

Contact Person: Reba Yow

Distance from Airport: 70 miles north of Little Rock, Ariansas. Type of Facility: 30 guest rooms located in private villas in the mountains.

Sizes of Meeting Rooms: 6 meeting rooms

Recreational Amenities: boating, fishing, game room, 18-nole goli course, tennis courts, outdoor heated swimming pool.

Rate Structure: unavailable

'was it originally a conference center? originally a rescrt

Ideas used to make your facility unique from others: unavailable

Percentage of business arriving by air, car, etc., and from what section of the country: majoritj of business arrives from Arkansas or Tennessee, Kentucky, Oklahoma, Missouri, etc. by car or bus.

Sources of your business: $35 \%$ business; $65 \%$ resort

Types of meetings most commonly held at jour facility: incentive meetings, management training meetings

Average attendance and duration of meetings: 35 persons, 5-7 dajs

Percentage of repeat business: $75 \%$ vacation business is repeat

Fatterns of weekly. and Jearly occupancy: spring and fall heaviest Facation months.

Reasons companies have chosen your facility over others and reasons they return: seclusion of meeting facilities.

Where is Jour major competition: none in immediate area 
Name of Facility: Salishan Executive Conference Center

Address: Highway 101, Glen Eden Beach, Oregon

Contact Ferson: Sandy Riverman, Conference Coordinator

Distance from Airport: 90 miles southwest of Portland International Airport.

Type of Facility: 150 guest rooms in a complex of 17 two-story wooden structures, spread out over 700 acres overlocking the ocean.

Sizes of Meeting Rooms: 10 meeting rooms, 3 in one area and 7 in nearby building; Long House Room, 53 x $85 \times 14$; Council House Room, $72 \times 36 \times 14$; Cedartree $44 \times 44 \times 9$; the Gallery, $36 \times 36 \times 9$.

Recreational Amenities: 18-hole golf course with PGA pro; 3 indoor and 1 outdoor tennis courts; health spa and gym. 5 miles of beaches; also fishing.

Rate Structure: European plan, seasonal, double $\$ 42-59$.

Was it originally a conference center? Conceived as a golf and beach resort and then conference facilities added.

Igess uged to make your facility unique from others: training of the stals with expertise in meeting planning; facility is environmentally conscious with jogging trail, etc.

Percentage of business arriving by air, car, etc., and from what section of the country: All guests arrive by bus, limo or car, having flown into Portland from the Pacific and Yountain states and some midivest states.

Sources of jour business: July and August, all vacation business; September through June, $60 \%$ business meetings, $40 \%$ vacation.

Types of meetings most commonly held at jour sacility: Small training sessions, incentive meetings, many government meetings.

Average attendance and duration of meetings: usual duration 3 nights; 50 - 70 people.

Percentage of repeat business: 50\% meetings, $75 \%$ vacation. Patterns of weekly and jearly occupancy: stated above

Reasons companies have chosen your facilitj over others and reasons they return: staff has been employed for long time and offers very experienced service. Companies are "not just treated like a number".

where is jour major competition: Actually, none in surrounding area. 
Name of Facility: Samoset kesort Inn

Address: F.O. Box 78, Narrentown street, Rockport, Maine.

Contact Ferson: Richard Gallagher, Sales Director

Distance from Airport: 90 miles from Portland Airport, 60 miles from Bangor jetport.

Type of Frcility: 150 ocean-view rooms in 4-stcry cedar and glass buildings. Located on 230 acres on Penobscot Bay.

Sizes of Neeting Rooms: 9 meeting rooms located on 2 floors. ilaine Room, nnox Room, Rockport Room, Camden Room, Rockland Rocm.

Recreational Amenities: outdoor and indoor heated swimming pool. Fealth spa and $\mathrm{gym}$, fishing peer, 1 indoor, 2 outdoor tennis courts, 18-hole Eolf course, sking nearby.

Rate Structure: European plan, seasonal. Single 325-38; double \$32-45; suites $352-92$.

Was it originally a conference center? desigred as combination resort and conference center.

Ideas used to make your facility unique from others: secluded location with excellent meeting facilities.

Percentage of business arriving by air, car, etc., and from what section of the country: all meetings business flies into 2 airports mentioned above and taken by airport bus or limo to facility.

Sources of your business: summer months are $85 \%$ vacation; rest of year is 50-50 business and resort.

Types of meetings most commonly held at jour facility: mostly training and sales-type meetings.

Average attendance and duration of meetings: 5-7 days, 30 people.

Percentage of repeat business:

75 ; vacation; 35,0 meetines

Patterns of weekly and gearly occupancy: see above

Reasons companies have chosen your racility over others and reasons they return: personal touch of staff and secluded surroundings

Where is jour major competition: none in immediate area 
Name of Facility: Scottsdale Conference Certer

Address: 7700 East McCormick Parkway, Scottsdale, Arizona

Contact Pergon: Kevin Mciahon, Director of Sales

Distance From Airport: 17 miles from Phoenix Sky Jarbor Internationa: Airport; 8 miles from Scottsdale Wunicipal Airport.

Type of Facility: year-round conference center comprised of 3story hotel complex with 204 rooms on 15 acres.

Sizes of Meeting Rooms: 18 meeting rooms; Apache $200 \mathrm{~m}, 106 \times 42$; Navajo Room, $74 \mathrm{x} 31$; Pueblo Room, $90 \times 42$; Colorado Room, $54 \mathrm{x} 31$.

Recreational Amenities: heated, outdoor swimming pool, 5 lit tennis courts, 2 paddle ball courts, nearbj ficcormick has 36-hole golf course, health club and gJm.

Rate Structure: full American plan, seasonal, singlo $955-90$, doubie $\$ 95-130$.

Was it originaliy a conference center? originally a conference conter des coned with most up-to-date audio-visual equipmert to cater Ideas used to make your facility unique from others: most up-to-date audio-visual equipment avaizable. Staff expertly trained to deal with corporate meeting planners.

Percentage of business arriving by air, car, etc., and from what section of the country: $75 \%$ of all business flies into phoenix from west coast, Midwest and some Northeast. Rest from surrounding areas.

Sources of jour business: 100\% corporate meetings business

Types of meetings most commonly held at jour facilitj: specializes in training meetings and sales type meeting.

Average attendance and duration of meetings: 5 days, 15-35 people

Percentage of repeat business: $75 \%$

Patterns of weekly and Jearly occupancy: spring and fall busiast meetings months, although all months have high occupancy.

Reasons companies have chosen your facility over others and reasons they return: excellent results of people holding meetings there.

where is your major competition: none with the superior audio-visual capabilities for training meetings. 
Name of Facility: Sea Pines Conference Center

Address: Sea Pines Plantation, Hilton Head Island, South Carolina Contact Ferson: Andy Radovic, Sales Representative

Pistance from Airport: 45 miles from Savannah's Travis Field Airport 10 miles to ilition iead Airport.

Type of Facility: 850 Villa condominiums with $1-4$ bedrooms. A 4500 acre golf, tennis and beach resort and a 500 acre forest preserve.

Sizes of Meeting Rooms: Larger Villas can be used for smaller meetings. Nithin walking distance are Harbour Town and Plantation Club Conference centers offering a total of 8 meeting rooms and

Kecreational Amenities: This ficility which is located within sea pines plantation has 60 tennis courts of which 13 are lighted. 2 driving ranges amd 3 golf courses, stables and 2 marinas.

Rate Structure: European plan. 1 bedrooms villa $50-752$ bedroom villa 70 - 110 .

was it originally a conference center? This is a condiminium, resort complex which lends itseli to the conference center idea.

Ideas used to make your facility unique from others: the abundance of facilities located on the island.

Percentage of business arriving by air, car, etc, and from what section of the country: Most business $(90 \%)$ arrives from either the local airport or through Savannah. Companies are comming from all over the United States and Europe, but especially from the East.

Sources of your business: The majorioy of businessifor this center consists of vacation and resort business, however $35 \%$ is meetings.

Types of meetings most cumonly held at jour facility: Nany incentive meetings and large sales meetings, many large professional organizations also hold meetings here

Average attendance and duration of meetings: 5 days, $75-100$ people

Percentage of repeat business: There is a $90 \%$ figure for repeat vacation business and $70 \%$ for repeat meetings business.

Patterns of weekly and jearly occupancy: Summer and holiday periods are exceptionally strong for vactioneers and spring and fall are the strongest for meetings.

Reasons companies have chosen jour facility over others and reasons the return: Excellent resort and meeting facilities in a beautiful location.

Where is jour major competition: Other resorts along the jouth carolo and Georgia Coast. 
Name of Facility: Shawnee In

(Harrison Conference Center)

Address: Shawnee on Delaware, Pennsylvania

Contact Person: Lee fagerquist, jastern Sales office

Distance from Airport: 75 miles from Newark International Airport;

90 miles from liew York.

Type of Facility: 86 guest rooms housed in 3 story mansion on

220 acre resort on banks of Delaware surrounded by pocono its.

Sizes of Meeting Rooms: 12 meeting rooms in total in main building Payette Room, $29 \times 56$; Fenry Room, $16 \times 36$; Laure1 Room, $16 \times 24$; Blake Room, $13 \times 28$.

Recreational Amenities: 27-hole golf course, 6 tennis courts, indoor and outdoor heated swimming pools, facilities for fishing and canoing.

Rate Structure: full American plan, single \$92; \$144 double.

Was it originally a conference center? Harrison converted it into a conference center.

Ideas used to make your facility unique from others: Earrison conference ideas.

Percentage of business arriving by air, car, etc., and from what section of the country: majority of business comes from Iast coast, usually take limo or private car to iacility.

Sources of your business: 100\% business meetings

Types of meetings most commonly held at jour facility: training meetings and sales meetings; management development meetings.

Average attendance and duration of meetings: 15-30 people, 3 to 5 days.

Percentage of repeat business: $90 \%$

Patterns of weekly and jearlj occupancy: see report

Reasons companies have chosen jour facility over others and reasons they return: Farrison name

where is jour major competition: none in immediate area 
Name of Facility: Sheraton International Conference Center

Address: 11810 Surrise Valley Drive, Reston, Virginia

Contact Ferson: Walter Chisling, Director of Warketing

Distance from Airport: 10 miles from Dulles International Airport 20 miles from iational Airport

Type of Facility: modern complex with U-shaped conference wing with 302 rcoms in a tower wing.

Sizes of Meeting Rooms: 22 meeting rooms of various sizes. Meeting rooms $A, B$, and $C$ are $107 \times 58$. D through $N$ are $26 \times 24$ and $I$ through 10 are $53 \times 45$.

Recreational Amenities: golf course on site, outdoor swimming pool 2 all-weather tennis courts and 9 indoor tennis courts;

Rate Structure: full-American plan, year-round; single 374 ; double $\$ 62$ per person.

was it originally a conference center? specifically designed in every way to be a full-serviced conference center.

Ideas uged to make your facility unique from others: U-shaped layout of meeting rooms and other facilities such as billiard room, jogeing tracks, rike rental make it excellent for executives.

Percentage of business arriving by air, car, etc., and from what section of the country: 50\% of all attendees arrive through 1 of 2 major airports. Other 50\% drive from areas like Philadelphia, Baltimore down to Richmond.

Sources of your business: Outside transient business is negligible; therefore making over $95 \%$ of all business related to meetings

Types of meetings most commcnly held at jour facility: many, many government meetings, professional association meetings, many multinational zroups holaing corporate meetings.

Average attandance and duration of meetings: 50-75 people, 3-4 days

Percentage of repeat business: $75 \%$ of business is repeat.

Patterns of weekly and Jearly occupancy: summer months and winter months fluctuate with lower occupancies.

Reasons companies have chosen jour facility over others and reasons thej return: Centralized Washington, D.C. location, close to airports and Jet not right downtown. 
Name of Facility: Silverado Resort and Conference Center

Address: 1600 Atlas Feak Road, Napa, California.

Contact Person: Randy Carter, Director of Sales

Distance from Airport: 65 miles from San Franciso International Airport.

Type of Facility: Cottages built around cclonial style mansion. 430 rooms located on 1200 acres in the heart of the Napa Valley wine district. Originally facility was a private estate.

Sizes of Meeting Rooms: 14 meeting rooms in total. Trophy $49 \times 57$, River $23 \times 50$, Red $14 \times 21$, Blue $16 \times 21$. These four are located in main building. Ten other rooms are brand new in another wing.

Recreational Amenities: 5 outdoor pools, 8 tennis courts, 2-18 hole golf courses, additioral tennis courts under construction.

Rate Structure: Zuropean plan, studio rooms 360 ; 1 bedroom suites, \$72; 2 bedroom suites $\$ 122 ; 3$ bedroom suites $\$ 150$.

was it originally a conference center? originally a golf and tennis resort, but with new additions is now considered conference resort.

Ideas used to make your facility unique from others: not available

Percentage of business arriving by air, car, etc., and from what section of the country: 50\% of business comes from San Francisco metropolitan area, 25\% out of L.A. area; $25 \%$ rest of country. Hajority of guests must take private limo or car into iacility. Sources of jour business: $30 \%$ of business meetings related while balance is resort-related.

Types of meetings most commonly held at jour facility: national sales meetings, executive training, professional and technical meetings.

Average attendance and duration of meetings: minimum of 50 persons ard up to 1 week duration of meetings.

Percentage of repegt business: resort business $75 \%$ repeat; meetings business $50 \%$.

Patterns of weekly and JearlJ occupancy: occupancy fairly consistent entire Juar with peak vacation times being summer and meeting times being spring and fall.

Reasons companies have chosen Jour facility over others and reasons they return: expertise of staff and geographic location.

where is jour major competition: resorts in ronterrey and on joast. 
Name of Facility: Snowmass Resort and Conference Center

Address: Box 5566, Snowmass Jillage, Colorado

Contact Person: Bud wilson, Sales Manager

Distance from Airport: 12 miles to Aspen Airport

Type of Facility: This facility has only meeting rooms and makes use of the over 3000 guest rooms in the resort village in over 18 hotels.

Sizes of Meeting Rooms: 25 meeting rooms with an additional

15 created with portable walls if necessary. Pavilion $75 \times 159 \times 30$ Opticon $88 \times 54 \times 30$, Timbermill $40 \times 88 \times 13$, Max Park $37 \times 55 \times 9$

Recreational Amenities: 17 outdoor swimming pools, snowmass Country club has 11 Tennis counts and an 13 hole Eolf course.

Rate Structure: Seasonal rates prevail in the area and range from Single 320 and Double $\$ 32$ in June through september. Jecemoer thru

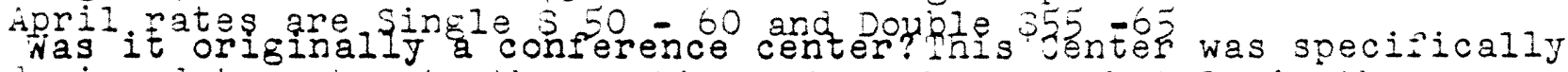
designed to cater to the meetings that the many hotels in the Inowmass area had booked facility unique from others: Not applicable

Percentage of business arriving by air, car, etc., and from what section of the country: Most meeting attendees arrive by air either thru Aspen or thru Denver and are bussed in.

Sources of your business: Sounces of business in most of the facilities is resort and vacation guests. Neetings business accounts for on the average $35 \%$ of thier business.

Types of meetings most commonly held at jour facility:

All types of meetings are held at the various hotels that use the Conierence Center.

Average attendance and duration of meetings: Usually $3-5$ days and $=0-100$ people

Percentage of repeat business: Not available

Patterns of weekly and jearly occupancy: Not available

Reasons companies have chosen jour facility over others and reasons they neturn: Companies choose snowmass Village because of the large number of excellent hotels and because the conference center will cater to all thien needs.

where is jour major competition: Aspen and Boulder Colorado 
Name of Facility: Sterling Forest Conference Center

Address: Sterling Lake Road, Tuxedo, New York

Contact Person: Narjorie Tillotson, Conference Planning Mgr

Distance from Airport: 35 miles from Laguardia Airport and 50 from J.F.X. International Airport

Type of Facility: 50 guest rooms are located in a complex of lodges. Located in a 22,000 acre forest preserve on Sterling lake. Set in natural landscaping.

Sizes of Meeting Rooms: A total of 5 meeting rooms are available and 6 - 8 smaller rooms can be used in the villas. Main Conference room $32 \times 40$, wand $18 \times 30$, Gibson $20 \times 24$ and Sterling $15 \times 25$.

Recreational Amenities: Sterling Lake has swimming, sailing and boating. Complete health spa and exercise room, 2 tennis courts, billiard room. Golf course, skiing, skeet shooting availablo at pearby countrye clubil American plan, single $\$ 100$, twin 3150.

Was it originally a conference center? former country homes purchased with idea of making conference center.

Ideas used to make your facility unique from others: total isolation allows for meeting concentration; close enough to $\mathrm{H}$. Y. for transportation.

Percentage of business arriving by air, car, etc., and from what section of the country: all business arrives by taxi, bus, or limo from N.V., N.J. or Conn.

Sources of jour business: $95 \%$ meetings business

Types of meetings most commonly held at jour facility: small executiv seminars, company training sessions, educational meetings, professione meetings.

Average attendance and duration of meetings: Monday - Saturday busios days. 15-25 people.

Percentage of repeat business: $90 \%$

Patterns of weeklJ and Jearly occupancy: summer months little slower as is December and January.

Reasons companies have chosen your facility over others and reasons the r return: companies chose this facility because attencees able to concentrate and still make use of excellent recreational facilities.

where is Jour major competition: Jarrison touse type facilities in ilew York and Connecticut. 
Name of Facility: Stonebridge Inn and Conference Center

Address: P.o. Box 5008, Snowmass Village, Colorado.

Contact Person: Cathy Evans, Director or Sales

Distance from Airport: 8 miles from Aspen Airport. 35 minute flight from Denver.

Type of Facility: 7 story Inn houses 100 rooms which are surrounded most oi the year by beatiful snow capped mountains.

Sizes of Meeting Rooms: 6 meetings rooms in total. Council $22 \times 76 \times 1$ Osage $22 \times 13 \times 10$, Three rooms are $22 \times 38 \times 10$ and the Comanche room is $22 \times 26 \times 10$.

Recreational Amenities: Heated outdoor pool, 1/z miles to snowmass Golf Course, riding stables and skiing in season.

Rate Structure: full-American plan, single $\$ 63$, double $\$ 94$.

Was it originally a conference center? mainly a ski rasort

Ideas used to make your facility unique from others: small size of facility allows for individual of meeting groups.

Percentage of business arriving by air, car, etc., and from what section of the country: $95 \%$ of all business comes from Aspen, remainder from Bus from Denver.

Sources of your business: majority of the year 65\% is vacetion business and $35 \%$ meetings business. This will vary in summer and winter months.

Types of meetings most commonly held at jour facility: Professional organizations, incentive groups and training meetings.

Average attendance and duration of metings: $50-75$ people, 5 days.

Percentage of repeat business: not available

Patterns of weekly and Jearly occupancy: see above section

Reasons companies have chosen jour facility over others and reasons they return: They like the personal service, and they like snowmass area better than Aspen.

where is Jour major competition: Other meeting Pacilities in ski resorts throughout Rockies. 
Name of Facility: Tarrytown House Conference center

Address: East Sunnyside Lane, Tarrytown, :ew Vork

Contact Person: Ann Finnerty, virector of Sales

Distance from Airport: 15 minutes from ivestchester airport, 27 miles to Laguardia and 40 miles to Kennedy Airport

Type of Facility: former Biddle Nansion with new addition. contains 130 guest rooms on 26 rolling, wooded acres uverlooking the Fudson.

Sizes of Meeting Rooms: 17 meeting room located throughout 3 buildings Auditorium, 63 x 28; East koom, $40 \times 23$ and 3 other meeting rooms approximately $28 \times 23$.

Recreational Amenities: 2 tennis courts, bowling, billiards, 2 miles from Ardsley Country Club with Eolf course. Cutdoor swimming pool.

Rate Structure: full American plan, $\$ 80$ twin per person and $\$ 115$ single includes everything.

was it originally a conference center? Estate was converted to a conference center.

Ideas used to make your facility unique from others: handle nothine but corporate clientele.

Percentage of business arriving bj air, car, etc., and from what section of the country: guests arrive by limo and car. Companies from all over U.S. fly executives in.

Sources of your business: $100 \%$ coppcrate meetings business

Tjpes of meetings most commonly held at jour facility: executive training meetings and other tjpes of training meetings; decision making meetings.

Average attendance and duration of meetings: 6-25 persons; 5 days

Percentage of repeat business: $\quad 95 \%$

Patterns of weekly and Jearlj occupancy: busy all jear except during holidays.

Reasons companies have chosen Jour facility over others and reasons they return: well-known reputation for catering only to upper curporate meetings market.

Where is your major competition: Sterling Forsst conierence center and Farrison Fouse Corference Center. 
Name of Facility: The Inn at Turtle Creek

Address: $\quad 3830$ Parkdale Drive, San Antonio, Texas

Contact Person: Judith Repash, Director of Sales

Distance from Aipport: 10 minutes from San Antonio International Airport

Type of gacility: 200 guest rooms in modern complex; 8 miles from downtown San Antonio.

Sizes of Meeting Rooms: 9 meeting rooms in total; ballroom, $90 \mathrm{x}$ 85; Lone Star Room, $60 \mathrm{x} 36$; Austin Room, $40 \times 33$; Travis Room, $24 \times 17$.

Recreational Amenities: 3 outdoor swimming pools, health club with gym, sauna, steam baths, 18-hole regular golf course, 11 outdoor tennis courts.

Rate Structure: year round Juropean plan, single, 4 li; double 348. Suites, \$100-150; full-American plan available.

Was it originally a conference center? designed to be combination resort and conference center.

Ideas used to make your facility unique from others: not available

Percentage of business arriving by air, car, etc., and from what section of the country: majority of business either flies or drives into $\mathrm{San}$ Antonio from state of Texas, Oklahoma, Louisiana.

Sources of your business: $35 \%$ business meetings; $65 \%$ resort and vacation.

Types of meetings most commonly held at jour facility: incentive anc training

Average attendance and duration of mettings: 4 days, 20 - 30 persons

Percentage of repeat business: $65 \%$ resort; $40 \%$ meetings

Eatterns of weekly and jearly occupancj: not available

Reasons companies have chosen jour facility over others and reascns the return: central Iexas location, beautiful country club surroundings.

Where is jour major competition: in Fouston ara Jallas aneas 
Name of Facility: Twin Sixties Inn and Conference Center

Address: 6060 i. Central Expressway, Dallas, Texas

Contact Person: Jim Mills, Director of Marketing

Distance from Airport: 30 miles from Dallas-Fort worth Airport 15 miles from Love Field Airport.

Type of Facility: Nidtown type facility with 300 guest rooms in 29 story builaing.

Sizes of Meeting Rooms: 11 meeting rooms include tine ballroom which divides into 4. Ballroom $94 \times 65$, Ballroom irorth $53 \times 37$ Executive $324 \times 38$ and Executive $430 \times 33$

Recreational Amenities: Swimming pool, health club

Rate Structure: Nodified American Plan, Single 44, double 54 suite $\$ 100-200$

was it originally a conference center? This is a commercial hotel that markets itself primarily to corporate meetings

Ideas used to make your facility unique from others: Eaving a downtown be able to provide top notch conference coordinating staff and facilities.

Percentage of business arriving by air, car, etc., and from what section of the country: $75 \%$ of the facilities business comes from Texas. They arrive 50\% by air and 50\% by private transportation.

Sources of your business: $25 \%$ transient, $25 \%$ tourist $50 \%$ meetings

Types of meetings most commonly held at jour facility: The larger type management meetings and sales meetings are most popular

Average attendance and duration of meetings: $50-75$ people for 2 - 3 days.

Percentage of repeat business: $50 \%$ of meetings business is repeat

Patterns of weekly and Jearly occupancj: Sunday through Thursday are the peak periods. The summer months and December and Januaury are slower meetings months.

Reasons companies have chosen jour Pacility over others and reasons they return: They like the central location of the facility in Jexas and like the expertise of the staff

where is Jour major competition: Other meeting facilities in Dallas, Fouston, New Orleans. 
Name of Facility: The Woodlands Inn and Country Club

Address: 2301 Millbend Drive, The Woodlands, Texas.

Contact Person: Chris Eerbert, Director of Sales

Distance from Airport: 14 miles north of Houston Intercontinental Airport

Type of Facility: Facility is located 35 miles from downtown Houston. The center is located on 335 acres of natural forest. There are

235 room including parlors and suites built into a lakefront setting.

Sizes of Meeting Rooms: There are 16 meeting rocms in total. Lakeside 60-75, French $30 \times 50$, Houston $80 \times 35$ and the Crockett $30 \times 40$.

Recreational Amenities: 2 outdoor swimming pools, sailing, boating and fishing on the private lake. Health club with gym. 21 outdoor tennis courts that are lighted and 3 indoor courts, 218 hole golf courses. (Eome of the Houst on Open)

Rate Structure: American plan, single from $\$ 85$, double from $\$ 130$.

Was it originally a conference center? Crizinall designed to be part of Noodlands new home town development. However, fit the conference center concent manased by executive conferences ltd. They have tried to incorpcrate all of the ideas from the best conference centers in the country into the center.

Percentage of business arriving by air, car, etc., and from what section of the country: $65 \%$ of all business flies into Houston Intercontinental Airport; the remainder of the business arrives from Fouston and Dalias area by car, as well as San Antonio and Austir. Sources of your business: $75 \%$ corporate, $25 \%$ vacation.

Types of meetings most commonly held at jour facility: many management decision-type meetings, incentive meetings and small sales groups Average attendance and duration of meetings: $35-40$ people, 4 days.

Percentage of repeat business: $75 \%$ meetings

Patterns of weekly and yearly occupancy: Yonday - Thursday, and Thursday - sunday. AII months have been consistent in occupancy.

Reasons companies have chosen jour facility over others and reasons they return: outside meeting rooms and audio-visual facilities.

where is your major competition: other meeting facilities in the Fouston and Jallas area. 


\section{E. haditional Information}

The fcllowine conference centers were contacted, but information wes not received in time to be incorporated into inis paper:

Konterey conference center - Honterey, Celifornia Ia coguille jxecutive center - Falm Beach, Floricia Eereamo conference center - Narcy, New York centre one - olevelana, ohio Southern Conference Center - ftlanta, Georeia Ferry chauncy conference Center - Princeton, liew Jersey

University of Chicago Conference center - Chicazo, IIIinois

The followine new conference centers are scheduled to open within the next six monthe (by the end of 1979):

The Houstonian, (A Fernison Conference Center) Ecuston, Texas

Incian Lakes Resort Hotel \& Conference Center Eloomington, Illinois

Sheraton Denver Technical Center - Denver, Colorado

$$
\text { F. Conciusion }
$$

fithough the conference center concept has only emerged within the last ten jears, the concept has caught on as a viable alternative to existing meeting facilities. Conference centers are now being built as part of condominium developments and resort complexes.

Conference centers are being specifically designed to provide for the continuine education and trainine of executives. 
Arnola, Davich, The Executive Conference Center: A Statistical and Einancial Profile. Philadelphia: Laventhol \& Fiorwath. (1977).

Finkel, colemar. "Weeting clinic." Successful leeting, July $2979, \mathrm{p} .25$.

Fishelman, Arthur. "You Owe It To Yourself to Try the Motal Learning Environment of a Conference center." Training, Tay $1978, \mathrm{pp} .43-46$.

Green, Walter. "Conference Centers and Training." Weetings and Conventions, February $2979, \mathrm{pp} .33,163$.

Green, walter A. "The Conference center concept." Weetings and Expositions, July 1973, pp. 16 - 20.

Foransisy, WeI. "Conference Centers: A Story of Growth and Chence." Meetings and Conventions, way 1979, pp. $30-32,30$.

Horansky, Wel. "what's liew in Conference Centers." Heetings anc Conventions, Kay $1979, \mathrm{pp} .36,42$.

Faiser, William $F$. "Conference Centers." Neetines and Expositions, september 1976, pp. $17-19$.

Iundberg, Donald E. The Hotel and Festaurant Eusiness. Soston: Canners Books International, Inc., 1976.

Rosenberg, Frederic D. "Conference Centers Expand." Weetines and Conventions, Hugust 1977, pp. $74-84$. 
"ratizins, Edrara. "yet the lietine Experts." Jospitality, septemider 1970, Fe. $50-52$.

"Conference centers, Fulfilline Zusiress's Fressing lieecss," Connel2 Guarter? E, Ebruary 1970 , pp. $24-34$.

"Gavel 2979 Anmual Directory of leetine Sites: "weetires exi Conventions, Harch 1979.

"Fotel and Travel Index," Volume 40, Lumber 1, Ziff-Devis Fublishine Company, liew York, Sprine 1979.

"The Neetines Varket, 1976-77," Meetines and Conventions Lasazine Annual Fieport, 1976 - 77 . 